Columbia Law School

Scholarship Archive

1999

\title{
The Legal Infrastructure of High Technology Industrial Districts: Silicon Valley, Route 128, and Covenants Not to Compete
}

Ronald J. Gilson

Columbia Law School, rgilson@law.columbia.edu

Follow this and additional works at: https://scholarship.law.columbia.edu/faculty_scholarship

Part of the Business Organizations Law Commons, Intellectual Property Law Commons, and the Science and Technology Law Commons

\section{Recommended Citation}

Ronald J. Gilson, The Legal Infrastructure of High Technology Industrial Districts: Silicon Valley, Route 128, and Covenants Not to Compete, 74 N.Y.U. L. REV. 575 (1999).

Available at: https://scholarship.law.columbia.edu/faculty_scholarship/992

This Article is brought to you for free and open access by the Faculty Publications at Scholarship Archive. It has been accepted for inclusion in Faculty Scholarship by an authorized administrator of Scholarship Archive. For more information, please contact scholarshiparchive@law.columbia.edu. 
NEW YORK UNIVERSITY

LAW REVIEW

\title{
THE LEGAL INFRASTRUCTURE OF HIGH TECHNOLOGY INDUSTRIAL DISTRICTS: SILICON VALLEY, ROUTE 128, AND COVENANTS NOT TO COMPETE
}

\author{
RONALD J. GILSON*
}

In recent years, scholars and policymakers have rediscovered the concept of industrial districts-spatial concentrations of firms in the same industry or related industries. In this Article, Professor Gilson examines the relationship between hightechnology industrial districts and legal infrastructure by comparing the legal regimes of California's Silicon Valley and Massachusetts's Route 128. He contends that legal rules governing evmployee mobility influence the dynamics of high technology industrial districts by either encouraging rapid employee movement between employers and to startups, as in Silicon Valley, or discouraging such movement, as in Route 128. Because California does not enforce post-employment covenants not to compete, high technology firms in Silicon Valley gain from knowledge spillovers between firms. These knowledge spillovers have allowed Silicon Valley firms to thrive while Route 128 firms have deteriorated. Professor Gilson concludes with three cautionary notes. First, the success of Silicon Valley firms suggests that per capita firm value will be greater where intellectual property protection is somewhat diluted, in contrast to the traditional law and economics prescription that emphasizes full protection of intellectual property. Second, the doctrine of inevitable disclosure, as developed in recent trade secret cases, threatens 10 undermine the advantages conferred by California's legal regime and should be considered with

* Charles J. Meyers Professor of Law and Business, Stanford University; Marc \& Eva Stern Professor of Law and Business, Columbia University. I am grateful to Stanford Law School and the Columbia University School of Law/Sloane Foundation Project on Corporate Governance for financial support, and to the Rockefeller Foundation, whose award of a residency at the Bellagio Study and Conference Center so greatly contributed to the completion of this Article. I also am grateful to Brian Hicks, Margaret McGinnis, Laura Menninger, Alex Gould, and Maria Ginzburg for their research assistance, and especially to Sean O'Connor for his outstanding assistance in constructing the history of the California law on restraints of trade. Joseph Bankman, Victor Goldberg, Jeffrey Gordon, Alan Hyde, Sam Issacharoff, Michael Klausner, Josh Lemer, Lance Liebman, and participants at workshops at the University of California at Berkeley, University of Chicago, Columbia University, New York University, Stanford University, and University of Virginia Law Schools, the School of International and Public Affairs at Columbia University, and the Stanford Graduate School of Business provided helpful comments on an earlier draft. 
caution. Third, other regions may not be able to emulate California's success simply by replicating its legal rules. Rather, policymakers in other states should consider the characteristics of local industries, weighing the advantages to those industries of knowledge spillovers against the reduced incentives for initial innovation that result from decreased employer intellectual property rights.

Policymakers have rediscovered the concept of industrial districts, especially high technology industrial districts. It is easy to understand the attraction. The threat of continued loss of well-paying manufacturing jobs to low wage countries has become a central political issue in the United States and other developed nations and a rallying cry for trade protectionists. The experience of regions like Silicon Valley and of what has come to be known as the "Third Italy"1 holds out the promise of the brass ring: new jobs with high wages. ${ }^{2}$ Hoping that similar names presage similar outcomes, regions christen themselves Silicon Mountain, Silicon Alley, Silicon Forest, or Silicon Glen.

The same phenomenon has also rekindled academic interest in the subject. The concept of an industrial district-the spatial concentration of firms in the same or a related industry-dates to Alfred Marshall writing in 1890.3 Marshall developed the concept of (and, unfortunately, the phrase) agglomeration economies to describe the input scale economies external to the firm but internal to the region that are available to any firm as a result of the proximity of similar firms. ${ }^{4}$ The input is available more cheaply within the region because of the spatial concentration of users. Marshall used the labor market as an example of this increasing-returns phenomenon. 5 As more firms in an industry locate in a region, workers with the skills demanded by the industry follow. The process is self-reinforcing: As more skilled workers locate in a region, other firms in the industry follow. The geographic concentration of firms results in a lower cost of skilled labor.

1 The term "Third Italy" distinguishes a number of successful regions largely in north and central Italy from "the impoverished South and the old industrial triangle of Genoa, Turin, and Milan." Charles F. Sabel, Flexible Specialisation and the Re-emergence of Regional Economies, in Reversing Industrial Decline? Industrial Structure and Policy in Brit* ain and Her Competitors 17, 22 (Paul Hirst \& Jonathan Zeitlin eds., 1989).

2 In 1996, Silicon Valley added some 50,000 jobs, while average wages grew at five times the national average. In the same year, the average wage in Silicon Valley was $\$ 43,510$, compared with $\$ 28,040$ nationally (in 1995 dollars). See John Markoff, A Gold Rush from Software Reinvigorates Silicon Valley, N.Y. Times, Jan. 13, 1997, at D1. As of 1990, wage rates in Italy's Emilia-Romagna region, which includes Carpi, Modena, and Bologna, were twice the national average, and per capita income, ranked seventeenth out of Italy's 21 regions in 1973, ranked second in 1986. See Bennett Harrison, Industrial Districts: Old Wine in New Bottles?, 26 Regional Stud. 469, 472 (1992).

3 Alfred Marshall, Principles of Economics 222-30 (8th ed. 16th prtg. 1964) (1890).

4 See id.

5 See id. at 225-26. 
Recent scholarship, styled the "new economic geography,"6 continues Marshall's stress on increasing returns in explaining industrial clustering, but with two important shifts in emphasis. First, reflecting the interest in high technology industrial districts evoked by their success, knowledge as an input subject to agglomeration economies receives central attention. Second, the new scholarship stresses the dynamics that give rise to industrial districts, rather than the equilibrium conditions that describe their existence. The result has been a recognition that industrial districts are path dependent-an industrial district's location may result not from the invisible hand of efficiency, but from "the details of the seemingly transient and adventitious circumstance"7 associated with its origin. In short, to understand the development and success of high technology industrial districts, "history matters."8

In this Article, I analyze a factor bearing on the location and development of high technology industrial districts that has not received attention in the economic geography literature: the legal infrastructure that supports the agglomeration economies and sustains regional concentrations of high technology firms. ${ }^{9}$ The special importance of legal rules to high technology industrial districts results from the new emphasis on knowledge as an input subject to increasing returns. The mechanisms and efficiency of knowledge transfer are shaped by two groups of legal rules: those governing intellectual property and, because tacit knowledge ${ }^{10}$ is most effectively transferred by the individuals in whom it is embedded, those relating to employee mobility. Thus, I will argue, legal infrastructure prominently influences the dynamics of high technology industrial districts.

I take as the context of my analysis the juxtaposition of two familiar U.S. high technology industrial districts: Silicon Valley on the San Francisco peninsula and Route 128 outside of Boston. The compari-

6 Masahisa Fujita \& Jacques-François Thisse, Economics of Agglomeration, $10 \mathrm{~J}$. Japanese \& Int'l Econ. 339, 341 (1996); Paul Krugman, Space: The Final Frontier, J. Econ. Persp., Spring 1998, at 161, 161.

7 Paul A. David \& Joshua L. Rosenbloom, Marshallian Factor Market Externalities and the Dynamics of Industrial Localization, 28 J. Urb. Econ. 349, 368 (1990) (arguing that spatial distribution of economic activity is highly sensitive to small differences in initial conditions).

8 Fujita \& Thisse, supra note 6 , at 371.

9 Alan Hyde, Real Human Capital: The Economics and Law of Shared Knowledge (May 1998) (unpublished manuscript, on file with the New York University Lav Review), also addresses the relation between legal rules and the operation of high technology industry. While our emphases differ, I have greatly benefited from Professor Hyde's interesting work.

10 "Tacit knowledge" is the skill or expertise, as opposed to easily codifiable information, that employees acquire through experience. See infra notes 23-24, 67 and accompanying text. 
son has two important advantages. First, it allows me the benefit of AnnaLee Saxenian's deep description of the history and operation of these districts, as well as her assessment of the reason for Silicon Valley's continuing success and Route 128's ultimate decline. ${ }^{11}$ Second, the comparison provides a natural experiment to test competing explanations for the two districts' differential performance. Consistent with the new economic geography, Saxenian stresses the comparative efficiency of interfirm knowledge transfer in Silicon Valley. In her account, knowledge is transferred between firms by the movement of employees between employers and to start-ups. ${ }^{12}$ She attributes Silicon Valley's efficiency advantage, and the resulting performance gap, to differences in the two regions' business cultures. ${ }^{13}$ Silicon Valley's culture of mobility - the constant penetration of local firms' open architecture by job-hopping engineers and the corresponding bias against vertical integration-is much more conducive to the regional distribution of innovative knowledge than Route 128's culture of career-long employment supported by more traditionally organized, vertically integrated firms.

I suggest here an alternative explanation for the two districts' differing efficiency at transferring knowledge between firms: differences in the districts' legal infrastructures, particularly the rules governing the enforceability of postemployment covenants not to compete. Such covenants are promises by employees not to compete with their employer, whether by working for a competitor or by starting a new business, for a period of time after employment terminates. In my account, the legal rules governing employee mobility are a causal antecedent of Saxenian's construction of a Silicon Valley business culture that supports job hopping and a Route 128 business culture that discourages it. The legal rules are one of the poles around which the shape of the business culture is formed.

The natural experiment results from the fact that Silicon Valley and Route 128 have different legal rules governing employment mobility. Postemployment covenants not to compete have the potential to restrict seriously the movement of employees between existing firms and to start-ups and, hence, to restrict seriously employee-transmitted knowledge spillovers. California prohibits covenants not to compete; ${ }^{14}$ Massachusetts enforces them. ${ }^{15}$

11 AnnaLee Saxenian, Regional Advantage: Culture and Competition in Silicon Valley and Route 128 (1994).

12 See id. at 34-37.

13 See id. at 111-17.

14 See infra Part III.B.3.

15 See infra Part III.B.2. 
My focus on the enforceability of postemployment covenants not to compete also responds to the concerns of the new economic geography. First, it ties the legal infrastructure directly to the mechanism that gives knowledge within an industrial district its characteristic of increasing returns. Knowledge, especially tacit knowledge, "spills over" between firms through the movement of employees between employers and to start-ups. Second, this aspect of the legal infrastructure dramatically illustrates the importance of initial conditions. The different legal rules governing postemployment covenants not to compete in California and Massachusetts help explain the differences in employee job mobility and therefore the knowledge transfer that Saxenian identifies as a critical factor in explaining the differential performance of Silicon Valley and Route 128. However, the difference in legal infrastructure does not result from the California legislature's efforts to provide the proper conditions for the development of high technology industrial districts. Rather, the California prohibition dates to the 1870 s, a serendipitous result of the historical coincidence between the codification movement in the United States and the new state's efforts at developing a coherent legal system out of its conflicting inheritance of Spanish, Mexican, and English law. The existence of this anachronistic legal rule during Silicon Valley's development precluded the collective action problem associated with encouraging employee mobility within a district.

Part I briefly develops the concept of agglomeration economies that give rise to industrial districts and then sketches the new economic geography's emphasis on knowledge spillovers and path dependency. Part II summarizes Saxenian's account of Silicon Valley and Route 128, which in turn tracks the new economic geography by focusing on knowledge spillovers as generative of agglomeration economies and on employee mobility as the means of interfirm knowledge transfer in Silicon Valley. Part III then offers an alternative explanation for the differences in employee mobility that Saxenian persuasively argues lie at the center of the two districts' differing performances. Saxenian emphasizes culture-laid-back California versus button-down New England.16 In contrast, I stress differences in the two districts' legal infrastructures-namely, the differential enforceability of covenants not to compete-as antecedent to differences in business culture. Part III also demonstrates how the California legal infrastructure solves the collective action problem associated with encouraging knowledge spillover through employee mo-

16 See Saxenian, supra note 11, at 50-57 (contrasting Silicon Valley's less formal and more open corporate culture with traditional hierarchical northeastern corporate culture). 
bility. Part IV then further develops the initial conditions that ultimately supported the continued success of Silicon Valley by tracing the origins of this critical aspect of Silicon Valley's legal infrastructure to the peculiar circumstances immediately following California's statehood. Part V concludes by offering a cautionary note with respect to the implications of my analysis for three related subjects: the standard law and economics prescription to protect fully intellectual property rights; a disturbing line of recent cases developing a doctrine of "inevitable disclosure" that threatens to turn trade secret law into the equivalent of a judicially imposed covenant not to compete; and the appropriate strategy for reforming a region's legal infrastructure to encourage or preserve high technology industrial districts.

I

Economic Geography: Agglomeration Economies, High TECHNOLOGY, AND INDUSTRIAL Districts

Economic geography seeks to explain "the location of factors of production in space."17 For our purposes, the object of the investigation is the presence of industrial districts: why firms in an industry locate in geographic proximity to each other. The policy motivation for the inquiry is readily apparent. If we can understand the conditions that produce high technology industrial districts, then we can provide a blueprint for regions seeking to preserve or increase the number and quality of available jobs.

The inquiry took modern form with Alfred Marshall's focus in 1890 on the potential for economies of scale external to the firm. ${ }^{18}$ The familiar concept of economies of scale internal to the firm contemplates that production costs will fall as firm output increases. Marshall, in contrast, was concerned with the effects of an increase in scale at the regional level. Firms would cluster in an industrial district if increased regional output - the scale of production outside the firmcaused input costs to decline. Marshall offered the cost of skilled labor as an example. As the number of employers of skilled workers within a region increases, workers with those skills are drawn to the region. As the number of skilled workers within a region increases, employers in need of workers with those skills are drawn to the region. ${ }^{19}$ The result, styled by Marshall an "agglomeration economy"

17 Paul Krugman, Increasing Returns and Economic Geography, 99 J. Pol. Econ. 483, 483 (1991) [hereinafter Krugman, Increasing Returns].

18 Marshall, supra note 3, at 225-30.

19 See id. at 225. Marshall explained further: 
and in later literature a "Marshallian factor market externality,"20 reflects generally the propensity for an input's relative price to be lower when the number of firms in a region that call for that input is higher. ${ }^{21}$

At this point, it is important to keep in mind the limited power of agglomeration economies in explaining the existence of industrial districts. An industrial district has two geographic characteristics, one relative and one absolute. The relative characteristic is the geographic relation of firms to each other-their proximity in space. An industrial district represents a spatial clustering of firms somewhere. The absolute characteristic is the actual location of the industrial districtits physical location. Agglomeration economies explain the relative characteristic of an industrial district-why firms are close together. The concept does not explain where in space the clustering occurs.

Spurred by the interest in high technology industrial districts, the new economic geography has continued Marshall's emphasis on increasing returns, but with two important shifts in emphasis. First, reflecting the interest in high technology industrial districts, attention has focused on knowledge as a critical input subject to agglomeration economies.22 Second, reflecting the policy motivation for the inquiry, more attention has been paid to understanding those elements of the phenomenon that traditional agglomeration economies may not ex-

When an industry has thus chosen a locality for itself, it is likely to stay there long: so great are the advantages which people following the same skilled trade get from near neighborhood to one another....

....

... Employers are apt to resort to any place where they are likely to find a good choice of workers ... while men seeking employment naturally go to places where there are many employers who need such shill as theirs....

Id.

20 See, e.g., Paul A. David et al., Marshallian Externalities and the Emergence and Spatial Stability of Technological Enclaves 1 (July 1996) (unpublished manuscript, on file with the New York University Law Review) (developing term "Marshallian factor market externality"). The same phenomenon should occur with other mobile factors of production that have industry-specific value.

21 The analysis necessarily assumes that transportation costs for the input are positive. While the discussion in the text suggests that the decline in input price results from a supply effect, input price is also affected by the risk sharing that can oocur from the clustering of employers. Assume that having to move one's residence to secure another job is costly to an employee. If the risk of unemployment because of the failure of a particular employer is not perfectly correlated with the demand for workers at other firms in the region, then the clustering of firms reduces the expected cost of unemployment to the employee. That, in turn, reduces the portion of the wage paid to compensate for unemployment risk. See David \& Rosenbloom, supra note 7, at 351-53.

22 Zvi Griliches, The Search for R\&D Spillovers, 94 Scandinavian J. Econ. S29 (Supp. 1992); reviews the literature in this area. 
plain, specifically, the dynamics of industrial districts-how they start, where they start, and, once started, their pattern of development.

That knowledge as an input is subject to increasing returns as a result of geographic proximity initially presents something of a puzzle. Precisely because of high technology, information has lost its geographic anchor. For example, the physical location of a law library is unimportant when the case reports are available electronically through Lexis or Westlaw. Nor does physical location matter very much when new scientific discoveries are immediately announced over the Internet. The reality of instantaneous communication through the World Wide Web has linked the world scientific community through electronic rather than physical proximity. From this perspective, the effect of technology should be to eliminate knowledgebased agglomeration economies: The more important knowledge is as an input, the less likely we should be to observe industrial clustering.

The puzzle disappears when one distinguishes between information on the one hand and knowledge or know-how on the other. The distinction is in the tacit character of knowledge-not the formal conception of an innovation, but the skill and experience associated with effectively creating, developing, and implementing it.23 Although advances in information technology may have caused the cost of transmitting the formal conception to become invariant to distance, effectively transmitting tacit knowledge requires proximity, and hence creates the potential for agglomeration economies. ${ }^{24}$ The need for proximity for knowledge transmission creates the potential for two kinds of agglomeration economies. Where tacit knowledge is acquired through a market relationship, as through the transmission of technological know-how by contract with a supplier, the potential for a Marshallian factor market externality exists. In contrast, informal transfer of tacit knowledge creates the potential for technological ex-

23 See Maryann P. Feldman, The Geography of Innovation 14 (1994); id. at 53 ("Some aspects of knowledge have a tacit nature that cannot be completely codified and transferred through blueprints and instructions."); David B. Audretsch \& Maryann P. Feldman, Innovative Clusters and the Industry Life Cycle, 11 Rev. Indus. Org. 253, 256 (1996) [hereinafter Innovative Clusters] (distinguishing tacit knowledge from information and noting that cost of transmitting former increases with distance); David B. Audretsch \& Maryann P. Feldman, R\&D Spillovers and the Geography of Innovation and Production, $86 \mathrm{Am}$. Econ. Rev. 630, 638 (1996) [hereinafter R\&D Spillovers] (arguing that due to importance of knowledge spillovers, propensity for innovative activity to cluster is higher in industries in which new economic knowledge plays greater role).

24 See Richard R. Nelson \& Sidney G. Winter, An Evolutionary Theory of Economic Change 76-82, 115-16 (1982) (describing tacit nature of skills); cf. Michael Polanyi, Personal Knowledge: Towards a Post-Critical Philosophy $49-65$ (1958) (describing skills as "the observance of a set of rules which are not known as such to the person following them"); id. at 69-77 (describing processes of learning). 
ternalities. In particular, the movement of workers between employers also serves to transfer tacit knowledge between firms.

Attention to the origins of agglomeration economies reveals the second characteristic of the new economic geography. The feedback process inherent in a Marshallian factor market externality-more firms [skilled workers] in a region leads to a migration of skilled workers [firms] to the region, which leads to a migration of more firms [skilled workers]-must start somewhere. However, nothing in the analysis thus far explains how or where the loop begins. Efforts to model the process suggest that the dynamics of district development are very sensitive to initial conditions; that is, the course of subsequent growth may depend importantly on small differences between regions at the outset. ${ }^{25}$ As Brian Arthur has put it, an industrial district may develop "not necessarily because of any intrinsic advantage of that particular location, but because 'historical accident' placed certain firms there initially and this concentration of firms in turn attracted [through the lure of agglomeration economies] a high proportion of subsequent entrants."26

The combination of (i) knowledge as an input giving rise to a Marshallian factor market externality, (ii) technological agglomeration economies, and (iii) the dependence on the history and initial conditions of an industrial district's actual location brings us to a final element of the economic structure of industrial districts: the life cycle of an industrial district. There is persuasive empirical evidence that the location of high technology industrial districts is associated with major university complexes. ${ }^{27}$ To be sure, that association is insuffi-

25 See generally, e.g., W. Brian Arthur, 'Silicon Valley' Locational Clusters: When Do Increasing Returns Imply Monopoly?, 19 Math. Soc. Sci. 235 (1990); David \& Rosenbloom, supra note 7; Fujita \& Thisse, supra note 6; Krugman, Increasing Returns, supra note 17.

26 Arthur, supra note 25, at 236; see also Krugman, Increasing Returns, supra note 17, at 487 ("[S]mall changes in the parameters of the economy may have large effects on its qualitative behavior. ... The story also suggests that the details of the geography that emerges-which regions end up with the population-depend sensitively on initial conditions."). David and Rosenbloom have observed:

[T] he sensitivity of the ultimate dynamic outcomes to small differences in initial conditions, or to relatively small shocks, allows realistic scope for historical events to play a role in the dynamies of spatial systems ... [ [which in turn] allow[s] the details of seemingly transient and adventitious circumstance to exert an enduring influence upon the spatial distribution of economic activity and population.

David \& Rosenbloom, supra note 7, at 368.

27 See, e.g., Innovative Clusters, supra note 23, at 271 (finding that university research leads to clustering of innovative activity at early and late stages of industry life cycles); R\&D Spillovers, supra note 23, at 638 (arguing that innovative activities tend to cluster where knowledge spillovers are high and where new knowledge is important); see also Lynne G. Zucker et al., Intellectual Capital and the Birth of U.S. Biotechnology Enter- 
cient to explain why Stanford gave rise to Silicon Valley and Harvard and MIT gave rise to Route 128, while similar phenomena were not associated with other major universities in the United States or elsewhere (an issue to which we will return in Part II). However, my concern here is not with the formation of a high technology industrial district, but with its subsequent development.

Assuming appropriate initial conditions, a combination of Marshallian factor market externalities and technological agglomeration economies can explain the initial phase of a high technology industrial district. A scientific innovation, likely linked to university-originated research and development, has the potential for commercialization. A university community, in turn, provides an initial population of scientifically trained workers to begin the commercialization process, thereby triggering the skilled worker/employer locational dynamic that creates an employee-related Marshallian factor market externality. At the same time, a technological agglomeration economy in the form of knowledge spillover from universities creates the opportunities for the new firm formations that demand skilled workers. ${ }^{28}$ But what influences the subsequent pattern of the district's development?

From this perspective, knowledge spillovers play a critical role. Start with an industrial district based on a particular set of products. Because tacit knowledge is critical to taking an innovation from conception to commercialization, the agglomeration economy at the development/commercialization stage is likely to be large, supporting significant geographical clustering. ${ }^{29}$ By contrast, tacit knowledge can be expected to play a lesser role during later stages in an industry's life

prises 1-3, 8, 11-13 (National Bureau of Econ. Research Working Paper No. 4653, 1994) (arguing that timing and location of birth of biotech enterprises is determined primarily by presence of intellectual capital, namely prolific "star" scientists).

28 For example, Zucker, Darby, and Brewer provide empirical evidence that "the timing and location of new biotech firms ... and new biotech subunits of existing firms . . . are primarily explained by the presence at a particular time and place of scientists who aro actively contributing to the basic science as represented by publications in major academic journals." Zucker et al., supra note 27, at 1; see also Neil Bania et al., Universities and the Startup of New Companies: Can We Generalize From Route 128 and Silicon Valley?, 75 Rev. Econ. \& Stat. 761, 765 (1993) (reporting positive relationship between local university research and firm creation in electrical and electronic equipment industries); Feldman, supra note 23 , at 89 (noting importance of university research and development to measures of regional innovation).

29 See Innovative Clusters, supra note 23, at 254:

[T]he propensity for innovative activity to geographically cluster will tend to be shaped by the stage of the industry life cycle... [T] he importance of tacit knowledge in generating innovative activity shapes the degree to which innovative activity will cluster. And the relative importance of tacit knowledge in generating innovative activity varies considerably across the various stages of the industry life cycle. 
cycle. "In the mature stage [of the industry life cycle,] most of the technical aspects of the product have become standardized, and the nature of demand is well known. At this point, the cost of transmitting information over geographic space becomes trivial." 30 The industry's focus becomes standardized production rather than innovation. Standardization, in turn, combines with the reduced influence of agglomeration economies of knowledge and the centrifugal force of congestion-the lower wage and land costs available outside the area because of the impact of clustering on the costs of fixed inputs-to cause the geographic dispersion of production. Commentators, for example, have described the dispersion of commodity-like semiconductor manufacturing from Silicon Valley to offshore sites as having followed this pattern. ${ }^{31}$

The story thus depicts a cyclical model of the development of a high technology industrial district. University-related scientific discovery gives rise to the tacit knowledge that creates cluster-inducing Marshallian and technological agglomeration economies, and initial conditions fix the cluster's physical location. With the product's maturity, the knowledge-based agglomeration economies dissipate, the value of physical proximity diminishes, and the industrial district diffuses. The question then is whether anything can interrupt this cycle of density giving way to diffusion.

At this point, the analysis shifts to the impact of knowledge spillovers on the district's capacity for continued innovation-the development of new products that will reset the industry life cycle. Here the literature stresses the importance of interfirm knowledge spillovers. Suppose research and development in an industrial district takes place within a large number of firms, the results of which are then shared among firms through both voluntary and involuntary knowledge spillovers. ${ }^{32}$ Voluntary spillovers occur through such mechanisms as joint ventures and cooperative supply relationships in which a mutual exchange of technology between a customer and supplier takes place. The benefits of such knowledge spillovers then accrue to the suppliers' other customers. Involuntary spillovers occur through the movement of workers to new employers. Tacit information associated with an employer's technology is embedded in the human capital of its employees. When an employee changes jobs, that

30 Id. at 259. See also Robin Cowan \& Dominique Foray, The Economics of Codification and the Diffusion of Knowledge, 6 Indus. \& Corp. Change 595, 604-05 (1997) (discussing process of codification of tacit knowledge).

31 See, e.g., Saxenian, supra note 11, at 93-95 (discussing movement of Silicon Valley's manufacturing to lower cost locations).

32 See generally sources cited supra note 23 . 
tacit information is available to the new employer. Commenting on involuntary information sharing in Silicon Valley, one of the founders of Intel pointed to "the mobility of our personnel, which quickly diffuses knowledge of new techniques in design, production, and marketing throughout the industry." ${ }^{33}$ These knowledge spillovers supercharge the innovative capacity of the district with renewed agglomeration economies, facilitating the development of new technologies that create a new industrial life cycle.

Economic geography thus tells a coherent story about the pattern of industrial districts. Agglomeration economies-Marshallian and technological - fuel the growth of a district whose physical location is dictated by initial conditions. The spatial attraction among firms is intense in the early stages of an industry's life cycle when knowledge spillovers are critical, only to dissipate as successful commercialization shifts emphasis from innovation to production. But knowledge spillovers between firms through voluntary cooperation and involuntary employee movement also have the potential to sustain the district's centripetal force by repeatedly restarting the industrial life cycle through new innovation-a form of "second-stage" agglomeration economy. And at this point our discussion of the two features of the new economic geography comes full circle: the importance of initial conditions as a determinant of the particular location of an industrial district reemerges. Just as initial conditions determine where among a range of alternative locations an industrial district actually arises, so too do they influence which among competing industrial districts develops a second-stage agglomeration economy and thereby resets its innovation cycle and overcomes the locational entropy of product cycle maturity. As we will see, the institutional capacity of a high technology industrial district to support knowledge spillover at this critical second stage, exemplified by the contrasting experiences of Silicon Valley and Route 128, also appears to depend importantly on historical accident. In the case of Silicon Valley and Route 128, I will argue, the historical accident is the different character of the two districts' legal infrastructures.

\section{II}

Silicon Valley Versus Route 128: Organizational and Performance Differences

This Part sets up a natural experiment concerning the importance of the legal infrastructure to the development of high technology industrial districts. The phenomenon that requires explanation is the

33 Robert N. Noyce, Competition and Cooperation-A Prescription for the Eighties, Res. Mgmt., Mar. 1982, at 13, 14. 
differential performance of Silicon Valley and Route 128. Route 128 began the race well ahead. In 1965, total technology employment in the Route 128 area was roughly triple that of Silicon Valley. ${ }^{34} \mathrm{By}$ 1975 , Silicon Valley employment had increased fivefold, but it had not quite doubled in Route 128, putting Silicon Valley about fifteen percent ahead in total technology employment. ${ }^{35}$ Between 1975 and 1990, the gap substantially widened. Over this period, Silicon Valley created three times the number of new technology-related jobs as Route 128.36 By 1990, Silicon Valley exported twice the amount of electronic products as Route 128,37 a comparison that excludes fields like software and multimedia, in which Silicon Valley's growth has been strongest. In 1995, Silicon Valley reported the highest gains in export sales of any metropolitan area in the United States, an increase of thirty-five percent over 1994; the Boston area, which includes Route 128, was not in the top five. ${ }^{38}$ What explains the improvement in Silicon Valley's performance, and the deterioration of that of Route $128 ?$

Saxenian's careful account of the causes of the performance differential reflects the lessons of the new economic geography. Different initial conditions, reflecting the two areas' different histories, account for the agglomeration and technological economies that originally gave rise to the two high technology industrial districts. However, differing patterns of industrial organization resulted in differing levels of interfirm knowledge spillovers and, in turn, differing capacities to create the second-stage agglomeration economy that can reset

34 See Saxenian, supra note 11, at 3 fig.1 (charting levels of total technology employment in Silicon Valley and Route 128 from 1959 to 1990).

35 See id.

36 See id. The same pattern appears if only semiconductor and electronic component jobs are considered. In 1959, Route 128 semiconductor companies employed approximately 27,500 workers, while Silicon Valley companies employed only 10,000. By 1970, the balance had reversed: Silicon Valley semiconductor companies employed 28,500 workers, while Route 128 employment had shrunk to 19,500 . By 1980, the difference was even more pronounced, with Silicon Valley employment rising to 64,000 , while Route 128 employment remained flat at 19,000. See id. at 79 fig.2 (giving employment figures for electronic component and semiconductor firms in Silicon Valley and Route 128 from 1959 to 1980).

37 See id. at 2 (stating that Silicon Valley exported electronic products worth more than $\$ 11$ billion in 1990, compared to Route 128's exports of $\$ 4.6$ billion).

38 In 1997, San Jose exported $\$ 29.06$ billion (just behind New York, which exported $\$ 29.08$ billion). The Boston area came in twelfth with $\$ 8.7$ billion of exports. See International Trade Admin., U.S. Dep't of Commerce, Export Sales of U.S. Metropolitan Areas, 1993-97 (visited Mar. 1, 1999) <http://www.ita.doc.gov/media/tdatapdf.htm>. Measuring success along a different dimension, it has been reported that the market capitalization of technology companies in and around Silicon Valley approximately equals that of the entire French stock market. See Silicon Valley: Introduction, Bus. Wk., Aug. 18, 1997, at 66, 66. In 1996, Silicon Valley's unemployment was $3.1 \%$ and its exports were rising at about $30 \%$ per year. See Louise Kehoe, The Valley's Magic Formula, Fin. Times, Aug. 25, 1997, at 13. 
the district's product life cycle. In this Part, I trace Saxenian's perceptive analysis of the industrial organization of Silicon Valley and Route 128 and how their differences influenced the existence of knowledge spillovers. In the next section, I take up the issue that Saxenian's account does not explain: why Silicon Valley developed the knowledgebased second-stage agglomeration economy that allowed the district to transcend its original product life cycle. Put differently, what initial conditions caused the second-round agglomeration economy to develop in Silicon Valley and not in Route 128 ?

\section{A. District Origins}

Both Route 128 and Silicon Valley had their origins in local universities. But while the Harvard/MIT complex for Route 128 and Stanford University for Silicon Valley provided the core around which each district grew, different events triggered the emergence of the industrial districts in these particular localities around these particular universities.

For Route 128, the critical event was the increase in defense spending on technology during World War II and the Cold War. MIT received more military funding during World War II than any other university, in no small measure due to the presence of an MIT professor, Vannevar Bush, as head of the government funding agency. ${ }^{39}$ This funding led to MIT's creation of the Radiation Laboratory. ${ }^{40}$ Similarly, Air Force funding during the early Cold War period led to the formation of Lincoln Lab at MIT in 1951.41 By the mid-1960s, Boston area university-related research labs employed some 5000 scientists and engineers. ${ }^{42}$ Consistent with the existence of agglomeration economies resulting from the concentration of skilled engineers, the area proved a fertile ground for commercial technology development. Lincoln Lab scientists founded more than fifty companies, including DEC, and scientists from the MIT Instrumentation Lab founded another fifty-five. ${ }^{43}$

Like Route 128, Silicon Valley took its modern shape after World War II. 44 While Hewlett-Packard and Litton Engineering Laboratories had formed in the 1930s, the initial conditions associated with

\footnotetext{
39 See Saxenian, supra note 11, at 13.

40 See id. at 14.

41 See id. at 16.

42 See id.

43 See Susan Rosegrant \& David R. Lampe, Route 128: Lessons from Boston's HighTech Community 93, 99 (1992).

44 This account draws on Saxenian, supra note 11, at 20-24, and Stuart W. Leslie \& Robert H. Kargon, Selling Silicon Valley: Frederick Terman's Model for Regional Advantage, 70 Bus. Hist. Rev. 435, 435-42 (1996).
} 
Silicon Valley's emergence lay in the efforts of Frederick Terman, an MIT Ph.D. and prewar Stanford engineering professor, who became Stanford's dean of engineering following World War II. ${ }^{45}$ Having been both a student of Vannevar Bush at MIT and director of Harvard's Radio Research Lab during World War II, Terman saw firsthand the potential benefits of university-industry collaboration. He returned to Stanford after World War II and pioneered Stanford's efforts to develop the agglomeration economies necessary to establish a high technology industrial district. He increased the size of the Stanford engineering program - by 1950, its award of doctoral degrees in electrical engineering equaled that of MIT-and led efforts to expand the range of university-industry knowledge spillovers. Stanford founded the Stanford Research Institute explicitly as a bridge between university research and commercial application. Stanford also initiated its Honors Cooperative Program, which encouraged engineers at local companies to enroll in graduate programs at the university, thereby formalizing university-company interaction. Finally, Stanford turned some of its own land adjacent to the campus into the Stanford Industrial Park, which assured that physical proximity would reinforce ties between the university and the electronics community. By 1961 , the industrial park housed twenty-five companies on over 652 acres. ${ }^{46}$

Thus, Marshallian factor market externalities and technological economies combined to support the growth of Route 128 and Silicon Valley as high technology industrial districts. The initial conditions that favored those universities and localities were different, with World War II federal research funds providing the trigger for Harvard/MIT and Route 128, and the efforts of Frederick Terman, in part shaped by his own experience in Boston, acting as the spur to Stanford and Silicon Valley. ${ }^{47}$

\section{B. Subsequent Development}

Saxenian's account of the differential performance of Silicon Valley and Route 128 centers on the strikingly different forms of industrial organization that came to characterize the two regions. From the

45 Prior to World War II, Terman had helped David Packard and William Hewlett, both then his students, found Hewlett-Packard by providing advice and a small personal investment. The garage on Addison Avenue in Palo Alto where the two graduate students worked has been designated by the State of California as "the birthplace of Silicon Valley." Leslie \& Kargon, supra note 44 , at $436,442$.

46 See Saxenian, supra note 11, at 23-24.

47 Leslie and Kargon note that just as Route 128 benefited from World War II defense expenditures in its early years, so too did Silicon Valley benefit from Cold War defense spending. See Leslie \& Kargon, supra note 44, at 470; see also Ann Markusen et al., The Rise of the Gunbelt: The Military Remapping of Industrial America 3, 5 (1991) (stressing importance of defense spending for U.S. high technology districts). 
outset, Silicon Valley developed a business structure that reflected nonlinear career patterns and a special status for entrepreneurs. The career paths of Silicon Valley engineers and managers resembled Brownian motion. They moved between companies, founded startups, supplied former employers, purchased from former employees, and in the course of their careers developed personal and professional relationships that cut across companies and competition. During the 1970s, employee turnover averaged more than thirty-five percent a year at the region's electronics firms; ${ }^{48}$ even in the severe recession in the semiconductor industry in 1984, twelve percent of a sample of Silicon Valley electronics production engineers quit their existing jobs for different employers. ${ }^{49}$ As Saxenian characterized the environment in Silicon Valley, "engineers shifted between firms so frequently that mobility not only was socially acceptable, it became the norm."so

Entrepreneurs occupy a special place in the Silicon Valley hierarchy. ${ }^{51}$ As Joseph Bankman and I have written elsewhere,

[i]n Silicon Valley, the defining myth takes as its stage David Packard's or Steve Jobs' garage. Palo Alto's Roland is the engineer who, with nothing but an idea and strength of character, leaves his job with an established company, starts a firm that becomes an industry leader, and in the process becomes fabulously wealthy. ${ }^{52}$

Literally scores of companies, including most prominently Intel, trace their origins to a founder's prior employment at Fairchild Semicon-

48 See Saxenian, supra note 11, at 34. Almeida and Kogut trace the employment pattern of engineers in the semiconductor industry who have secured patents on their research. They report that "Silicon Valley is clearly unique in terms of inter-firm mobility." Paul Almeida \& Bruce Kogut, Localization of Knowledge and the Mobility of Engineers in Regional Networks 16 (Aug. 5, 1998) (on file with the New York University Law Review).

49 See David P. Angel, The Labor Market for Engineers in the U.S. Semiconductor Industry, 65 Econ. Geography 99, 103 (1989) (concluding that results of survey "indicate substantial labor mobility among semiconductor production engineers and confirm the expectation of frequent job changing by these highly skilled workers").

50 Saxenian, supra note 11, at 34. One engineer told Saxenian, "Two or three years is about $\max$ (at a job) for the Valley because there's always something more interesting across the street. You don't see someone staying twenty years at a job here." Id. at 35. The comment of another engineer captures the absence of friction in moving between jobs associated with a Marshallian factor market externality:

[In Silicon Valley] it wasn't that big a catastrophe to quit your job on Friday and have another job on Monday and this was just as true for company executives. You didn't necessarily even have to tell your wife. You just drove off in another direction on Monday morning. You didn't have to sell your house, Id. and your kids didn't have to change schools.

51 Saxenian reports that "[t]he culture of the Valley accorded the highest regard to those who started firms." Id. at 38.

52 Joseph Bankman \& Ronald J. Gilson, Why Start-ups?, 51 Stan. L. Rev. 289, 289-90 (1999). 
ductor, which itself was formed by engineers leaving Shockley Transistor Corporation. As Saxenian notes, former Hewlett-Packard executives alone founded eighteen start-ups between 1974 and 1984.53

The result of what Alan Hyde calls a "high velocity labor market"54_rapid employee movement both between employers and in connection with founding start-ups-is a pattern of industrial organization in which firms are remarkably porous to outside influence. Firms have not vertically integrated because smaller start-ups could provide parts more cheaply and effectively. In turn, the availability of a full range of suppliers reduces the capital necessary to found a startup; virtually everything but the idea can be subcontracted out.ss Moreover, even vertical integration could not effectively protect a company's trade secrets; too many employees would move to competitors carrying their employer's know-how with them (while the employer in turn would benefit from an inflow of employees from other employers).

Thus, Silicon Valley's form of industrial organization institutionalized the knowledge spillovers that constitute the second-stage agglomeration economy critical to resetting an industrial district's production life cycle. With this local industry structure, a single company need not be a technological leader in every stage of a product's manufacturing process. Instead it can specialize in one stage, whether research and design or fabrication, and rely on suppliers or customers to provide cutting edge technology at other stages. In Saxenian's account, knowledge spillovers facilitated by the mobility of employees and the resulting bias against vertical integration turn the entire industrial district into an engine of continuous innovation, thereby transcending the life cycle of any single product.

Route 128 firms, in contrast, developed in more traditional fashion, imitating the vertically integrated structures of the large massproduction company. ${ }^{56}$ In contrast to the Brownian motion of Silicon Valley's high velocity employment, career patterns of employers and managers in Route 128 companies were much more linear. Knowledge workers anticipated long-term employment with a single employer and career development that contemplated rising vertically

53 See Saxenian, supra note 11, at 116. Silicon Valley's fascination with start-ups also has efficiency advantages. A large literature suggests that the small companies are more likely sources of innovation. See Bankman \& Gilson, supra note 52, at 299-302 (surveying literature).

54 Hyde, supra note 9, at 3.

55 See Saxenian, supra note 11, at 40 (noting that "hundreds of small design firms, contract manufacturers, metalworking shops, software developers, and prototyping operations made their homes in Silicon Valley," facilitating growth of start-ups).

56 See id. at 70. 
within an organization, rather than success through lateral movement, as in Silicon Valley. ${ }^{57}$ As Saxenian emphasizes, "[t]he practice of leaving a large company to join a small firm or a promising new start-up was virtually unheard of." 58 Consistent with this pattern, Route 128 gave rise to traditionally vertically integrated companies; in this locality, knowledge transfer took place within, rather than across firms. ${ }^{59}$ As a result, learning and innovation were company-specific exercises. Missing was the knowledge spillover and the corresponding secondstage agglomeration economy associated with information dissemination through employee mobility and the absence of vertical integration. To be sure, particular companies in Route 128 created innovative products, but the performance of the district as a whole deteriorated. The district was unable to reset the product life cycle consistently, with a resulting decline across the region.

\section{Explanations for the Organizational and Performance Differentials}

Saxenian's account provides three-quarters of the elements necessary to explain the origins and different trajectories of the Silicon Valley and Route 128 high technology districts. Consistent with the new economic geography, a complete story must account for four elements: (i) the initial conditions and (ii) associated agglomeration economies that explain both the location and original success of the two districts, and (iii) the initial conditions and (iv) associated secondstage agglomeration economy whose presence has allowed Silicon Valley to reset its product life cycle and whose absence has contributed to Route 128's decline. The story so far explains the initial conditions and agglomeration economies that gave rise to Silicon Valley and Route 128, and the agglomeration economy present in Silicon Valley and absent in Route 128 that allowed Silicon Valley to recreate the district continually. What is missing is item (iv): an account of the initial conditions whose presence facilitated the second-stage agglomeration economy in Silicon Valley and whose absence hindered its development in Route 128.

57 See Almeida \& Kogut, supra note 48 , at 30 tbl.5 (reporting that patent-holding Silicon Valley engineers in semiconductor industry change jobs within that region eight times more frequently than do similar engineers in Route 128 region).

58 Saxenian, supra note 11, at 63 . The differential in the founding of start-ups is startling. According to Saxenian, the largest wave of start-ups in Silicon Valley history began in the late 1970s and continued during the 1980s. See id. at 117. During the same period, the rate of start-ups in Route 128 declined. See id. at 125. In 1981, for example, venture capitalists funded only 17 start-ups in Massachusetts, while funding 37 in Silicon Valley. See id. at 64.

59 See id. at $69-70$ (describing development of vertically integrated "self-sufficient" firms in Route 128 region). 
Saxenian's tale of two districts does reveal the basic mechanism whose differential availability must be explained. The second-stage agglomeration economy results from intercompany, intradistrict knowledge spillovers that cause the entire district to function as an innovation laboratory. These spillovers result from the pattern of extreme employee mobility characteristic of Silicon Valley and absent in Route 128. The web of knowledge spillovers, personal relations, startup businesses, and absence of vertical integration owes its existence to the ease with which employees move from employer to employer, from established company to start-up, from customer to supplier, taking their employer's tacit knowledge with them and applying it in their new situations. Lacking the ability to prevent knowledge spillovers, Silicon Valley companies adapted to their environment, and the characteristic Silicon Valley industrial organization evolved.60 But that leaves us with the missing item: Why did high velocity employment evolve in Silicon Valley and not in Route 128? What were the initial conditions associated with the second-stage agglomeration economy?

Saxenian offers a partial but, in the end, incomplete answer: culture or "social structure."61 In Silicon Valley the absence of a prior culture allowed the development of a new one-one which reinforced open social and professional relations. These open relations also "functioned as efficient job search networks,"62 critically important in a culture in which "[t] he preferred career option ... was to join a small company or a start-up, rather than an established company. The superiority of small, innovative firms over large corporations became an article of faith among many of the region's engineers." 63

The culture in Route 128 differed. "The conservative social traditions and attitudes of New England also shaped the organization of

60 The story is one in which initial conditions lead to the adoption of complementary institutions-those that make existing institutions more productive. Development of the system thus moves in a domino-like fashion as existing institutions give rise to associated institutions that provide this fit. See Paul Milgrom \& John Roberts, Complementarities and Fit: Strategy, Structure, and Organizational Change, 19 J. Acct. \& Econ. 179, 180, 190 (1995) (using complementarity theory to suggest that effective firm structures change to optimize fit with environment); Paul Milgrom \& John Roberts, Complementarities and Systems: Understanding Japanese Economic Organization, 9 Estudios Económicos 3, 4 (1994) (using complementarity theory to interpret characteristic features of Japanese economic organization as being particularly well adapted to Japan); Paul Milgrom \& John Roberts, The Economics of Modern Manufacturing: Technology, Strategy, and Organization, $80 \mathrm{Am}$. Econ. Rev. 511, 526-27 (1990) (concluding that clustering of high-tech firms is result of exploitation of complementarities that simultaneously increase manufacturing quality and decrease production costs).

61 Saxenian, supra note 11, at 29. See also id. at 2-4 (arguing that Silicon Valley's less formal social and business structures explain its success relative to Route 128).

62 Id. at 34.

63 Id. 
local labor markets and patterns of entrepreneurship. Stability and company loyalty were valued over experimentation and risk-taking in the Route 128 region."64 Thus, in Saxenian's account, cultural differences in the two regions provide the crucial initial conditions that led to different employment patterns and, ultimately, to different patterns of industrial organization only one of which-Silicon Valley's-would produce a second-stage agglomeration economy.

But why did Silicon Valley culture develop differently from Route 128? Accepting Saxenian's description of the two districts, her proffer of culture as the causal agent of the critical differences in employee career patterns ultimately is unpersuasive. Standing alone, cultural explanations are incomplete accounts of the characteristics of economic institutions. It is hardly surprising that culture and economically successful institutions are mutually supportive; the intriguing result would be if the two conflicted. But the correspondence between culture and economics leaves open the question of causation, ${ }^{65}$ a matter of great importance if part of the goal is to understand the structure necessary to support a high technology district.

The new economic geography and Saxenian's description of Silicon Valley and Route 128 thus combine to leave us with a critical question: What initial conditions gave rise to the regions' critically different employment patterns? As Paul Krugman puts it, "given a slightly different sequence of events, Silicon Valley might have been in Los Angeles, Massachusetts, or even Oxfordshire."66 And that brings us to the influence of the legal infrastructure.

\section{III}

The Legal Infrastructure of High Technology INDUSTRIAL DISTRICTS

In Part II's account of the second-stage agglomeration economy whose presence explains Silicon Valley's capacity to reset the district's product cycle, employee mobility plays the central role. Much of a high technology firm's intellectual property is informal in character, embedded in the human capital of its employees. As Robert Merges has explained:

64 Id. at 62.

65 See Ronald J. Gilson \& Mark J. Roe, Lifetime Employment: Labor Peace and the Evolution of Japanese Corporate Governance, 99 Colum. L. Rev. (forthcoming 1999) (manuscript at 6, on file with the New York University Law Review) (arguing that "hindsight can give the illusion of causation" but, without more, "random sequencing and tight causation are equally compelling").

66 Paul Krugman, Complex Landscapes in Economic Geography, 84 Am. Econ. Rev. 412,415 (1994). 
A great deal of the relevant information is in the form of trade secrets or "tacit" knowledge and know-how. ... Accounts of industrial $R \& D$ and invention almost universally mention the importance of hands-on experience, much of it gained over time and in the course of interactions with other researchers, manufacturing personnel, and marketing experts in the firm. ${ }^{67}$

This element of the employer's intellectual property is embedded in the employee's human capital, and can be most effectively transferred through proximity and, in particular, by an employee changing jobs. Thus, employee mobility is the mechanism by which the requisite knowledge spillover occurs. But an individual employer has an obvious competitive interest in protecting its intellectual capital which, in the case of trade secrets and tacit knowledge, is accomplished by restricting employee mobility. Individually rational employer efforts to protect intellectual property ultimately conflict with the collectively rational conditions necessary to the knowledge spillovers that support the second-stage agglomeration economy.

The legal infrastructure of a high technology industrial district mediates this tension between intellectual property protection on the one hand, and employee mobility on the other. This Part describes the complementary legal rules that both determine the character of intellectual property rights and shape the terms of the employment relation. Demonstrating how the California and Massachusetts rules differ in these two critical respects is the first step toward identifying differences in the districts' legal infrastructures and highlighting an important initial condition that ultimately helped shape their experiences.

I should take up at the outset a straightforward response to the importance this account accords the aspects of the legal infrastructure bearing on employee mobility. If encouraging interemployer spillovers of trade secrets and tacit knowledge through employee mobility results in a second-stage agglomeration economy, and if the average per firm value of that economy exceeds the corresponding average per firm cost of weakened intellectual property protection, then the legal infrastructure should be irrelevant. Individual firms acting in their own self-interest will elect not to interfere with employee mobility, resulting in a self-enforcing equilibrium of high velocity employment.68

67 Robert P. Merges, Property Rights Theory and Employee Inventions in Corporate Governance Today 19 (Apr. 28, 1998) (unpublished manuscript, on file with the New York University Law Review).

6S I have in mind here Robert Ellickson's study of the difference between the rules actually applied by the community and the law on the books in resolving cattle disputes in 
The difficulty with this account of self-organization is the familiar coordination barrier to collective action. While it would be in the interest of the region's firms collectively to facilitate employee mobility even at the expense of diluting the intellectual property of individual firms, it will be in the interest of any individual firm to impede the mobility of its own employees. Such a firm gets the benefit of the region-wide spillover of other firms' intellectual property without incurring the cost of diluting its own. Some coordinating mechanism is necessary to achieve (and perhaps maintain) the equilibrium, which brings us back to the role of the legal infrastructure. ${ }^{69}$ Whether because Silicon Valley firms did not realize the regional advantages from employee mobility, or because of the difficulty of coordination, local firms' initial response to employee mobility reflected an individually rational strategy. As Saxenian describes, early in the district's development employers responded to departing employees by taking legal action. Only the failure of these efforts led to employer acceptance of high velocity employment. ${ }^{70}$

Our inquiry thus starts with the ability of Silicon Valley firms to prevent knowledge spillovers through employee mobility. As we will see, the regime of high velocity employment appears to have resulted from the legal infrastructure's failure to provide complete protection for an important category of intellectual property. The inability to

Shasta County, California. Residents developed and applied their own rules independent of the formal legal infrastructure. See Robert C. Ellickson, Order Without Law: How Neighbors Settle Disputes (1991).

69 Professor Roe and I consider a similar claim with respect to the absence of an external labor market associated with Japanese lifetime employment. Our analysis suggests, consistent with the text, that individual firm self-interest will prevent the evolution of a self-enforcing equilibrium. See Gilson \& Roe, supra note 65 , at 2 . We conclude that establishing the equilibrium observed over most of the post-World War II period in Japan required government coordination. See id. at 15-16. Robert Bone nicely demonstrates the difficulty of reaching a coordination outcome by means of a Rawlsian behind-the-veil analysis. See Robert G. Bone, A New Look at Trade Secret Law: Doctrine in Search of Justification, 86 Cal. L. Rev. 241, 291-92 (1998).

70 See Saxenian, supra note 11, at 35. Indeed, occasional outbursts of employer hostility to employee mobility continue to occur. According to accounts in advertisements taken out by Oracle Corporation in the San Francisco Chronicle and on billboards along U.S. 101 (which runs by Oracle headquarters), 11 computer programmers at Informix, an Oracle competitor, left Informix and joined Oracle in January 1997. See Advertisement, "They are treating us like runaway slaves.", S.F. Examiner, Mar. 9, 1997, at B7. According to the Oracle advertisement, the day the employees quit, the CEO of Informix confronted the CEO of Oracle at his home, asking Oracle "to return the eleven 'runaway' employees." Id. The next day, Informix sued each of the departing employees. See id. Oracle appeared to be taking some pleasure in the event, with the advertisement offering the following advice to various interested parties: "Advice to Informix: Hire programmers not lawyers. . . . Advice to Informix programmers: Negotiate your legal fees upfront. Advice to Informix customers: Call Oracle." Id. 
prevent knowledge spillovers through employee mobility proved to be one pole around which Silicon Valley's business culture and industrial organization precipitated.

\section{A. Protecting Tacit Knowledge and Inventions Through Trade Secret and Invention Law}

\section{Tacit Knowledge}

Trade secret law provides the most straightforward source of protection for an employer's tacit knowledge that has become embedded in an employee's human capital. Stated generally, employees retain the right to use their general and industry-specific human capital when they move to a new position. However, they cannot make use of an employer's trade secrets; conceptually, at least, employers have the right to prevent employees from "spilling over" tacit knowledge that constitutes a trade secret. If the employer can prove that the new employer of a former employee has used its trade secrets, a variety of remedies are available, including injunctive relief and damages. The problem, however, is that trade secret law provides less effective protection than may at first appear.

The line between the employee's general and industry-specific knowledge on the one hand, and the employer's trade secrets on the other, is drawn by the Uniform Trade Secrets Act (UTA), ${ }^{71}$ which has been adopted in one form or another by the majority of jurisdictions (including California). ${ }^{72}$ The UTA defines a trade secret as:

information, including a formula, pattern, compilation, program, device, method, technique, or process, that: (i) derives independent economic value, actual or potential, from not being generally known to, and not being readily ascertainable by proper means by, other persons who can obtain economic value from its disclosure or use, and (ii) is the subject of efforts that are reasonable under the circumstances to maintain its secrecy. ${ }^{73}$

71 Unif. Trade Secrets Act (amended 1985), 14 U.L.A. 437 (1990 \& Supp. 1998).

72 See Restatement (Third) of Unfair Competition $\$ 39$ statutory note at 437-38 (listing states adopting Uniform Trade Secrets Act (UTA) or other civil trade secret statute of general applicability). In addition to the District of Columbia, the following states have adopted the UTA or other trade secret statutes: Alabama, Alaska, Arizona, Arkansas, California, Colorado, Connecticut, Delaware, Florida, Georgia, Hawaii, Idaho, Illinois, Indiana, Iowa, Kansas, Kentucky, Louisiana, Maine, Maryland, Massachusetts, Minnesota, Mississippi, Montana, Nebraska, Nevada, New Hampshire, New Mexico, North Carolina, North Dakota, Ohio, Oklahoma, Oregon, Rhode Island, South Carolina, South Dakota, Utah, Virginia, Washington, West Virginia, and Wisconsin.

73 Unif. Trade Secrets Act § 1(4) (amended 1985), 14 U.L.A. 437-38 (West 1990). The California statute differs from the UTA in that it omits from clause (i) the phrase "and not being readily ascertainable by proper means." See Cal. Civ. Code $\$ 3426.1$ (West 1997). 
While Massachusetts has not adopted the UTA, ${ }^{74}$ its common law definition of a trade secret is for practical purposes identical. ${ }^{75}$

The definition establishes the elements of the cause of action for misappropriation of a trade secret-the mechanism by which an employer would protect its tacit knowledge from spilling over to a competitor by means of an employee's departure. The original employer would have to show that the former employee's new employer "misappropriated"76 information of the original employer, that the information was not generally known, and that the original employer had made reasonable efforts to protect the information's secrecy. From the perspective of an original employer seeking to protect competitively sensitive tacit knowledge, two problems are readily apparent. The first is substantive, the second procedural.

This omission has the effect of providing broader protection than the UTA, a point I will consider below, see infra text accompanying notes 101-03.

74 See Roger M. Milgrim, 1 Milgrim on Trade Secrets $\S 1.01[2][b]$ (1998) [hereinafter Milgrim on Trade Secrets].

75 See, e.g., CVD, Inc. v. Raytheon Co., 769 F.2d 842, 850 (1st Cir. 1985) (defining trade secret as "any formula, pattern, device or compilation of information which is used in one's business, and which gives him an opportunity to obtain an advantage over competitors who do not know or use it" (internal quotations omitted in original) (quoting Eastern Marble Prods. Corp. v. Roman Marble, Inc., 364 N.E.2d 799, 801 (Mass. 1977) (quoting Restatement (First) of Torts $\$ 757 \mathrm{cmt}$. b (1939)))). The Restatement (Third) of Unfair Competition defines a trade secret as "any information that can be used in the operation of a business or other enterprise and that is sufficiently valuable and secret to afford an actual or potential economic advantage over others." Restatement (Third) of Unfair Competition $\S 39$ (1995). The reporters state with respect to section 39 that "[t]he concept of a trade secret as defined in this Section is intended to be consistent with the definition of 'trade secret' in $\$ 1(4)$ of the [UTA]." Id. $\$ 39 \mathrm{cmt}$. b.

76 Section 1 of the UTA defines "misappropriation" as:

(i) acquisition of a trade secret of another by a person who knows or has reason to know that the trade secret was acquired by improper means; or

(ii) disclosure or use of a trade secret of another without express or implied consent by a person who

(A) used improper means to acquire knowledge of the trade secret; or

(B) at the time of disclosure or use, knew or had reason to know that his knowledge of the trade secret was

(I) derived from or through a person who had utilized improper means to acquire it;

(II) acquired under circumstances giving rise to a duty to maintain its secrecy or limit its use; or

(III) derived from or through a person who owed a duty to the person seeking relief to maintain its secrecy or limit its use; or

(C) before a material change of his [or her] position, knew or had reason to know that it was a trade secret and that knowledge of it had been acquired by accident or mistake.

Unif. Trade Secrets Act $\S 1$ (2) (amended 1985), 14 U.L.A. 438 (West 1990). For the Massachusetts statute codifying the tort action available for trade secret infringement, see Mass. Gen. Laws Ann. ch. 93, § 42 (1997). 
The substantive problem relates to the imprecision of the lines that the UTA requires a litigant to establish. The distinction between tacit knowledge embedded in the employee's human capital that "derives independent economic value, actual or potential, from not being generally known," and an employee's general or industry-specific human capital is blurred at very best. Similarly uncertain are what efforts to maintain secrecy are "reasonable under the circumstances," and therefore required by the UTA as a condition to trade secret protection. Articles by California practitioners provide a lengthy litany of protective activities that would help establish the requisite effort to maintain secrecy, ${ }^{77}$ but all are expensive and some are likely to interfere with the actual conduct of the business. This latter point is especially important. When lawyers design procedures that are inconvenient for those who actually must implement them, the procedures tend to be ignored. From an evidentiary standpoint, adopting and then ignoring a procedure is more damaging than never having adopted it at all, since the adoption undermines the argument that the procedure was unnecessary in the first place. Finally, the matter remains a judgment call for the trier of fact.

The procedural problem derives from the substantive problem. Precisely because the distinctions the UTA requires a plaintiff to establish are imprecise, trade secret litigation is likely to be expensive and slow. The frequency with which phrases like "knows [knew] or has [had] reason to know" or "reasonable under the circumstances" appear in the statute is a fair metric for the breadth of discovery by the defendant. ${ }^{78}$ Moreover, it is quite unlikely that such issues will be resolvable by summary judgment.79 In every case, the plaintiff will

77 See, e.g., Victoria A. Cundiff, Protecting Computer Software as a Trade Secret (PLI Patents, Copyrights, Trademarks, and Literary Property Course Handbook Series No. G44042, 1998); Marina C. Tsatalis \& Timothy Klima, Protecting Trade Secrets from Malicious Employees, in Legal Documentation for Start-up and Emerging Companies 1 (Education Comm. of the Bus. Law Section, State Bar of California, 1997) (deseribing requirement that "reasonable efforts" must be made to maintain secrecy); Gary E. Weiss et al., Protecting Trade Secrets: A Primer for California Start-ups, in Legal Documentation for Start-up and Emerging Companies, supra, at 5-6 (listing items to consider in order to achieve "reasonable efforts" to protect trade secrets, including manuals, confidential stamps, posted warnings, security guards, key-lock entries, encryption, document shredding policies, and logs of persons requesting sensitive information).

78 See supra note 76 (setting out statutory definition of misappropriation).

79 Judge Posner said with respect to the original employer's obligation to maintain secrecy:

But only in an extreme case can what is a "reasonable" precaution be determined on a motion for summary judgment, because the answer depends on a balancing of costs and benefits that will vary from case to case and so require estimation and measurement by persons knowledgeable in the particular field of endeavor involved.... There are contested factual issues here, bearing in 
have to take seriously the threat that the matter will actually have to be tried, with the resulting uncertainty associated with a jury trial on technical issues. ${ }^{80}$

In short, litigation seeking to protect an employer's trade secrets from spilling over by a former employee's taking with her the employer's tacit knowledge has two important characteristics that are amusingly (albeit distressingly) highlighted in tongue-in-cheek quips that I have heard from commercial litigators. The first has counsel for a potential trade secret plaintiff advising her client that "no price is too high for justice." In contrast, the second has counsel for the potential defendant advising her client that "justice delayed is justice." On balance, trade secret law does not seem to provide a significant barrier to high velocity employment and, at least in California, it apparently has not.

Care must be taken not to overstate the argument. Trade secret law does have force. Actions in response to theft and industrial espionage, because they are unlikely to involve tacit knowledge, are not subject to the same level of ambiguity associated with efforts to restrict employee mobility. And significant protection is provided even against departing employees in circumstances where the misappropriation is clear (as when the former employee has removed or copied documents), the technology obviously secret, and the damage to the business substantial. ${ }^{81}$ But it remains the case that protection is limited with respect to the kind of knowledge spillovers that give rise to a second-stage agglomeration economy. In this regard, one should keep in mind that the practical considerations weighing against employee litigation will grow with the development of the industrial district, thus

mind that what is reasonable is itself a fact for purposes of Rule 56 of the civil rules.

Rockwell Graphic Sys., Inc. v. DEV Indus., Inc., 925 F.2d 174, 179-80 (7th Cir. 1991). Note also that Judge Posner's reference to "estimation and measurement by persons knowledgeable in the particular field" can be fairly read to invite a contest of expensive experts and a parallel round of expert discovery.

80 A third concern involves the danger that the litigation process itself will result in the disclosure of the trade secret to third parties whose subsequent use of the trade secret will not violate the UTA because the third party will not have "misappropriated" the information. In California, for example, Civil Procedure Code section 2019 requires that "the party alleging the misappropriation shall identify the trade secret with reasonable particularity." Cal. Civ. Proc. Code $\S 2019$ (d) (West 1998). To be sure, in any action under the UTA the court is directed to "preserve the secrecy of an alleged trade secret by reasonable means." Cal. Civ. Code $\$ 3426.5$ (West 1997). However, the practical difficulty of adequately policing the large number of third parties who will come to know the trade secret as a result of contested litigation, even with the assistance of various protective orders, represents a significant deterrent to commencing the litigation in the first place.

81 In addition to state criminal law, the Economic Espionage Act of 1996 imposes federal criminal penalties for trade secret theft. See 18 U.S.C. $\$ \S 1831-1839$ (Supp. II 1996). 
continually raising the value threshold that must be crossed before it will be worthwhile to initiate trade secret litigation against a former employee. In my analysis, the absence of legal barriers to high velocity employment provides the pole around which a complementary business culture precipitates. Once a business culture supportive of high velocity employment is established, trade secret litigation against former employees is not only expensive and uncertain, but also risks the imposition of labor market-imposed reputation penalties against the unusual employer who sues a departing employee. Hyde provides examples of this phenomenon; 82 the recent Oracle-Informix controversy provides yet another. ${ }^{83}$ Thus, as the high technology industrial district takes form, the costs of a former employer pursuing trade secret litigation against departing employees rise. Given the initial conditions, local employment practices evolve toward a self-enforcing equilibrium.

\section{Inventions}

Legal rules provide the employer little more comfort when an employee leaves with a new invention to form a start-up than they do when an employee leaves with tacit knowledge to work for a competitor. Who owns an invention discovered by an employee depends on the stage of the inventive process at which the question is asked. The critical point in the process is "conception," defined as "the first occurrence of the complete invention in the mind of the inventor-as corroborated by objective evidence." 84 Under the law of inventions, ideas remain the employee's property until conception. And because conception requires the employee to take the affirmative step of creating written corroboration, an employee can choose to delay this event until after he leaves the company. ${ }^{85}$

To be sure, the earlier in the invention process an employee must make the decision to undertake a start-up, the riskier is the employee's human capital investment in the venture. ${ }^{86}$ However, it is important to stress that the litigation burden of proving conception

82 See Hyde, supra note 9, at 137-40 (describing "reputational sanctions" imposed on IBM and Intel after they sued departing employees).

83 The Oracle-Informix incident is recounted supra note 70.

84 Merges, supra note 67, at 37 (emphasis added).

85 See id. at 37-38. For present purposes, we can ignore statutory and common law differences in the default rules regarding invention ownership that depend on whether the employee was hired to do research, whether the inventing employee used employer resources in the invention process, and whether the invention related to the employer's existing or contemplated business. As long as the employee leaves before the invention's formal conception, the ownership rules influenced by these considerations do not apply.

86 See Bankman \& Gilson, supra note 52, at 306 n.44. 
rests with the former employer who is claiming ownership. Thus, the former employer will have to acquire through discovery precisely the documents that a legally sophisticated Silicon Valley employee knows would be damaging. This knowledge allows the former employee to behave strategically with respect to such documents, by not turning over documents that he has made, by not retaining them, or by not creating them in the first place.

That leaves the application of trade secret law to preconception inventions. Here too, however, protection fails. Merges states with respect to this concern that "while trade secret law protects pure information in theory, in practice trade secret actions by ex-employers are rarely successful where the former employee(s) take nothing tangible with them." 87

\section{B. Protecting Tacit Knowledge and Inventions Through a Covenant Not to Compete}

Were trade secret law the only way to protect employers against spillovers of proprietary knowledge through employee mobility, the legal infrastructure would be an unlikely candidate to explain the initial conditions that led to the different experiences of Silicon Valley and Route 128. Simply put, the legal infrastructures of the two districts do not differ in material respects along this dimension: The scope of protection provided by trade secret law in California and Massachusetts appears to be roughly the same.

Employers, however, have recourse to another, more effective way to prevent employee-disseminated spillovers of employer proprietary knowledge. If the critical mechanism by which spillovers occur is employee mobility, then an employer could secure protection by causing employees to sign postemployment covenants not to compete. In contrast to trade secret law, the legal infrastructures of Silicon Valley and Route 128 differ dramatically along this dimension.

\section{The Operation of Covenants Not to Compete}

A postemployment covenant not to compete prevents knowledge spillover of an employer's proprietary knowledge not, as does trade secret law, by prohibiting its disclosure or use, but by blocking the mechanism by which the spillover occurs: employees leaving to take up employment with a competitor or to form a competing start-up. Such a covenant provides that, after the termination of employment for any reason, the employee will not compete with the employer in the employer's existing or contemplated businesses for a designated

87 Merges, supra note 67 , at 38 . 
period of time-typically one to two years-in a specified geographical region that corresponds to the market in which the employer participates.

The effectiveness of such provisions reflects the limited useful life of knowledge in high technology industries. Given the speed of innovation and the corresponding telescoping of product life cycles, knowledge more than a year or two old likely no longer has significant competitive value. The hiatus imposed by a covenant not to compete thus assures that a departing employee will bring to a new employer only her general and industry-specific human capital. The value of proprietary tacit knowledge embedded in the employee's human capital, or the value of inchoate inventions the employee has strategically chosen not to bring to conception during her employment, will have dissipated over the covenant's term. Nothing of value is left to spill over to a new employer or start-up venture.

The availability of such a covenant has an obvious impact on the potential for an industrial district to develop a second-stage agglomeration economy like the one that has allowed Silicon Valley to reset its product cycle. The covenant puts a sharp brake on employee mobility, and thus on the knowledge spillovers that give rise to the critical second-stage agglomeration economy. The widespread use and enforcement of covenants not to compete slow down high velocity employment to the point where the level of knowledge spillovers is too low to support a districtwide innovation cycle.

It is with respect to the availability of covenants not to compete that the character of the legal infrastructure helps explain the initial conditions that gave rise to the different experiences of Silicon Valley and Route 128. Under Massachusetts law, postemployment covenants not to compete generally are enforceable. Under California law, they are not. As we will see, this difference in starting points helps explain the different capacities of the two industrial districts to generate the second-stage agglomeration economy necessary to reset a district's product cycle.

\section{The Enforceability of Covenants Not to Compete \\ Under Massachusetts Law}

Massachusetts law is generally representative of the approach taken toward postemployment covenants not to compete by the great majority of states. United States law in this area largely derives from English law that developed the basic pattern of blanket enforcement of covenants not to compete given by the seller in connection with the sale of a business, and the application of a rule of reason to covenants associated with employment. Covenants not to compete would be en- 
forced against a departing employee if the covenant's duration and geographic coverage were no greater than necessary to protect an employer's legitimate business interest, and not otherwise contrary to the public interest. 88 This formulation is commonplace in Massachusetts covenant cases, ${ }^{89}$ and dates to the late nineteenth century. ${ }^{90}$

88 See generally Anthony C. Valiulis, Covenants Not to Compete 166-68 (1985); Harlan M. Blake, Employee Agreements Not to Compete, 73 Harv. L. Rev. 625, 629-51 (1960). As related by Valiulis, the development of English law regarding enforceability of postemployment covenants not to compete tells an interesting tale of economic history. The earliest statutes and caselaw, quite hostile to employment restrictions, are said to have grown out of the extreme labor shortage following the Black Death in 1348. See Valiulis, supra, at 155-57. In 1349, for example, the Ordinance of Labourers was enacted which, in effect, made voluntary unemployment a crime. See id. at 156-57. Dyer's Case denied enforcement of a bond against competition by a former employee, with the comment by one of the judges that "[b]y God, if the plaintiff were here he should go to prison until he paid a fine to the King." Blake, supra, at 636 \& n.33 (quoting Dyer's Case, Y.B. 2 Hen. 5, 5, Mich. 26 (C.P. 1414)). Changing economic circumstances, including the rise and decline of the guilds, led to the development of a rule of reason. See Valiulis, supra, at 157-65.

The general approach in the United States is set out in Restatement (Second) of Contracts:

(1) A promise to refrain from competition that imposes a restraint that is ancillary to an otherwise valid transaction or relationship is unreasonably in restraint of trade if

(a) the restraint is greater than is needed to protect the promisee's legitimate interest, or

(b) the promisee's need is outweighed by the hardship to the promisor and the likely injury to the public.

(2) Promises imposing restraints that are ancillary to a valid transaction or relationship include .... :

$\cdots$

(b) a promise by an employee or other agent not to compete with his employer or other principal....

Restatement (Second) of Contracts $\S 188$ (1981).

89 See, e.g., Edgecomb v. Edmonston, 153 N.E. 99, 101-02 (Mass. 1926) (enjoining defendant, pursuant to covenant, from engaging in any line of business similar to plaintiffs within city of Boston, and from soliciting plaintiff's customers within Massachusetts for period of five years); Quincy Oil Co. v. Sylvester, 130 N.E. 217, 218 (Mass. 1921) (applying rule of reason analysis, considering contract in light of business, situation of parties, circumstances under which contract was made, and scope and purpose of contract); Ferrofluidics Corp. v. Advanced Vacuum Components, Inc., 968 F.2d 1463, 1468-69 (1st Cir. 1992) (interpreting Massachusetts law as permitting restrictive covenant so long as it was necessary for protection of employer, reasonably limited in time and space, and consonant with public interest); Allied Adjustment Serv. v. Heney, 484 A.2d 1189, 1191 (N.H. 1984) (interpreting Massachusetts law as permitting "reasonable" covenants not to compete).

Massachusetts law is flexible in that a court will trim down, to the point that it is enforceable, an otherwise valid covenant whose duration or geographic coverage is too great. See, e.g., All Stainless, Inc. v. Colby, 308 N.E.2d 481, 485-86 (Mass. 1974) (upholding two-year covenant not to compete but restricting geographical area to territory serviced by salesman prior to termination).

90 Blake, supra note 88, at 644, dates the rule of reason formulation in Massachusetts to Morse Twist Drill \& Mach. Co. v. Morse, 103 Mass. 73 (1869) (upholding covenant not to compete based on nature of business, scope and purpose of covenant, and circumstances under which covenant was made). 
Massachusetts caselaw developing the circumstances when a covenant not to compete will be enforceable is large, somewhat inconsistent, and uses the language of trade secret law quite loosely. In particular, judicial discussion of the interests of an employer sufficient to support enforcement typically refers to a litany of acceptable concerns: the protection of trade secrets, confidential information, and goodwill. ${ }^{91}$ This formulation raises the possibility that a covenant not to compete adds nothing to the trade secret protection that applies without a separate covenant (and, therefore, that applies in California). For present purposes, my goal is neither to survey, nor to reconcile judicial precedent in Massachusetts, but rather to focus on outcomes. In this respect, Massachusetts law accords significant impact to the presence of a postemployment covenant not to compete. A recent discussion by a Massachusetts practitioner captures the additional protection provided by a covenant:

It is often a practical impossibility for a former employee to work in the same industry for a competitor without employing or disclosing, even unconsciously, the intellectual property of the former employer. Indeed, that intellectual property constitutes only one end of the spectrum of the information, knowledge and expertise that an employee develops in the course of working for an employer. The demarcation line between such information, knowledge and expertise and truly proprietary information may not be ascertainable. Even if it were, it is difficult or impossible for a company to determine whether a former employee is honoring the obligation to refrain from using information that is clearly over the line and into the category of trade secrets. In these circumstances, a covenant not to compete can provide an added measure of protection. ${ }^{92}$

91 See, e.g., New England Canteen Serv., Inc. v. Ashley, 363 N.E.2d 526, 528-29 (Mass. 1977) (refusing to enforce noncompetition covenant absent showing of goodwill or similar interest damaged by former employee's competition); Marine Contractors Co., Inc. v. Hurley, 310 N.E.2d 915, 919 (Mass. 1974) (upholding covenant not to compete where consideration was paid); All Stainless, Inc, 308 N.E.2d at 485-86 (upholding two-year covenant not to compete but restricting geographical area to territory serviced by salesman prior to termination); Richmond Bros., Inc. v. Westinghouse Broad. Co., Inc., 256 N.E.2d 304, 307 (Mass. 1970) (refusing to enforce covenant not to compete against former employee where competition would be merely "ordinary" and former employee knew no trade secrets); Weils v. Wells, 400 N.E.2d 1317, 1319 (Mass. App. Ct. 1980) (holding that "employee covenants not to compete are enforceable only to the extent they are necessary to protect the legitimate interests of the employer"); National Hearing Aid Ctrs., Inc. v. Avers, 311 N.E.2d 573, 577 (Mass. App. Ct. 1974) (refusing to enforce covenant against employee who did not appropriate any confidential customer information belonging to employer).

92 J. Charles Mokriski, Trade Secrets: Protect Your Competitive Edge-or Perish, Mass. Law. Wkly., May 30, 1994, at 33, available in Westlaw, ALLNEWS database. Comprehensive Techs. Int'l, Inc. v. Software Artisans, Inc., 3 F.3d 730, 739 (4th Cir. 1993), makes the same point: 
And the outcomes of litigated cases reflect the likelihood of enforcement: Of the ten decisions on preliminary injunctions to enforce covenants not to compete between February 1994 and July 1996, injunctions were granted in eight..$^{93}$ Of special importance, the availability of preliminary injunctive relief with respect to covenants not to compete contrasts sharply with the unavailability of summary judgment in the case of misappropriation of trade secrets. ${ }^{94}$

In any event, my purpose is not to show that covenants not to compete are uniformly enforceable under Massachusetts law. Rather, I seek to establish only that Massachusetts law presents an initial condition which could give rise to the Route 128 employment pattern, industrial organization, and business culture that Saxenian describes. A significant probability that a postemployment covenant not to compete will be enforced, as clearly seems to be the case under Massachusetts law, would dictate a different career strategy. The risk to employees from changing employers (and the risk to employers of hiring the former employees of competitors) or organizing a start-up would encourage an employee to stay in her current job. The resulting dynamic would favor long-term career patterns, vertical integration, and, ultimately, internal rather than districtwide innovation. The initial condition-a legal infrastructure that impedes employee mobility-generates a complementary business culture and institutions that, once established, support a self-enforcing equilibrium.

Importantly, this aspect of Route 128's legal infrastructure would not interfere with the industrial district's original development. Route 128 grew out of university-related agglomeration economies, a plentiful supply of skilled labor due to the presence of Harvard and MIT, and the knowledge spillovers resulting from the university-run World War II and Cold War research labs. ${ }^{95}$ Because those laboratories were nonprofit organizations, it is highly unlikely that they secured cove-

When an employee has access to confidential and trade secret information crucial to the success of the employer's business, the employer has a strong interest in enforcing a covenant not to compete because other legal remedies often prove inadequate. It will often be difficult, if not impossible, to prove that a competing employee has misappropriated trade secret information belonging to his former employer.

93 See Edmund C. Case, Recent Developments in "Non-Compete" Litigation, Mass. Law. Wkly., July 15, 1996, at 11, available in Westlaw, ALLNEWS database.

94 See Robert P. Merges et al., Intellectual Property in the New Technological Age 89 (1997) ("In a competitive industry, preventing the disclosure of trade secrets is far preferable to suing for misappropriation after they have already been disclosed. A noncompetition agreement may be a reasonable way for an employer to prevent a problem-and a lawsuit-before it starts."); see also supra note 79 (describing barriers to summary judgment in trade secrets cases).

95 See supra notes $39-43$ and accompanying text. 
nants not to compete from their employees. Consistent with this analysis, a large number of Route 128 start-ups, including DEC, were founded by scientists leaving these labs. ${ }^{96}$ However, the legal infrastructure would present a barrier to the second-stage agglomeration economy that sustains a high technology district by allowing it to reset its product life cycle, an economy that did not develop in Route 128 but did in Silicon Valley.

\section{California Law Governing Covenants Not to Compete}

California law governing covenants not to compete is both unusual and radically different from that of Massachusetts. California Business and Professions Code section 16600 provides that "every contract by which anyone is restrained from engaging in a lawful profession, trade, or business of any kind is to that extent void."97 The courts have interpreted section 16600 "as broadly as its language reads." 98 Other than two statutory exceptions (which track the general rule outside of California) allowing enforcement of covenants not to compete associated with the sale of a business, 99 the statute's prohibition is essentially unqualified. For example, covenants that seek to avoid the policy by penalizing, rather than prohibiting, postemployment competition are also prohibited.100 While there are decisions suggesting in dicta that California courts may enforce a covenant not to compete when it is necessary to protect trade secrets, ${ }^{101} \mathrm{I}$ have un-

96 See supra text accompanying note 43 (noting that scientists from MIT's Lincoln Lab founded 50 companies and that scientists at MTT's Instrumentation Lab founded 55).

97 Cal. Bus. \& Prof. Code $\$ 16600$ (West 1997).

98 Scott v. Snelling \& Snelling, Inc., 732 F. Supp. 1034, 1042 (N.D. Cal. 1990).

99 The statutory exceptions cover sales of a business whether effected through the sale of the business's assets, the sale of shares in a corporation, or the sale of a partnership interest. See Cal. Bus. \& Prof. Code $\$ 16601$ (West 1997) (sale of goodwill or corporation shares; agreement not to compete); id. $\S 16602$ (partners; dissolution, dissociation, or sale; agreement not to compete).

100 See, e.g., Beneficial Life Ins. Co. v. Knobelauch, 653 F.2d 393, 396 (9th Cir. 1981) (invalidating under section 16600 employment contract term that required departing employee to repay advances if employee competed); Muggill v. Reuben H. Donnelly Corp., 398 P.2d 147, 149 (Cal. 1965) (in bank) (invalidating retirement plan term that caused former employee to forfeit annuity payments if employee engaged in competing business); Ware v. Merrill Lynch, Pierce, Fenner \& Smith, Inc., 100 Cal. Rptr. 791, 796-97 (Ct. App. 1972) (invalidating under section 16600 profit-sharing plan term that caused former employee to forfeit benefits if employee engaged in competing business), affd, 414 U.S. 117 (1973).

101 See, e.g., Scott, 732 F. Supp. at 1043 (stating that "California courts recognize a judicially created exception to section 16600 and will enforce a restrictive covenant" to protect employer's trade secrets); Trans-American Collections, Inc. v. Continental Account Servicing House, Inc. 342 F. Supp. 1303, 1305 (D. Utah 1972) (observing that in California, covenant not to compete may be enforceable where necessary to protect trade secrets); Muggill, 398 P.2d at 149 (holding that covenants not to compete are unenforceable "unless 
covered no case in which a California court actually enforced a covenant not to compete on that basis. ${ }^{102}$ Indeed, California courts' application of choice of law rules underscores the seriousness with which they view section 16600 . Even if the employment agreement which contains a postemployment covenant not to compete explicitly designates the law of another state, under which the covenant would be enforceable, as controlling, and even if that state has contacts with the contract, California courts nonetheless will apply section 16600 on behalf of California residents to invalidate the covenant. ${ }^{103}$

Perhaps there is a California case that I have missed which enforces a covenant not to compete. But just as I did not attempt in the previous section to establish that Massachusetts courts always enforced covenants not to compete, I do not seek here to demonstrate that California courts never enforce a covenant not to compete (although I would not be surprised by that outcome). Rather, my more limited point is that California's legal infrastructure made it extremely unlikely that postemployment covenants not to compete would be enforced. Coupled with the limited usefulness of trade secret law in California as elsewhere, Silicon Valley employers' early efforts to prevent employees from leaving to compete by using employers' proprietary tacit knowledge failed.104 Employees learned that they could leave; employers learned that they could not prevent high velocity employment and the resulting knowledge spillover. And that legal infrastructure caused employers, however reluctantly, to adopt a different strategy, one of cooperation and competition, that generated a dynamic process leading to Silicon Valley's characteristic

they are necessary to protect the employer's trade secrets"); Fowler v. Varian Assocs., Inc., 241 Cal. Rptr. 539, 544-45 (Ct. App. 1987) (holding that discharging employee for good cause for assisting employer's competitors did not violate free competition policy behind section 16600, as "agreements designed to protect an employer's proprietary information do not violate section 16600 ").

102 Scott declined to enforce a covenant not to compete because it found no trade secrets to protect. See 732 F. Supp. at 1043-45. Trans-American Collections, Inc. upheld a covenant not to compete under Colorado law; its statement of California law was dictum. See 342 F. Supp. at 1305. Muggill neither involved trade secrets, nor upheld anything; instead the case voided under section 16600 a provision of an employment agreement that terminated pension benefits if a former employee competed. See 398 P.2d at 149. Fowler merely upheld the discharge of an employee who actively assisted the employer's competitor; no covenant not to compete was involved. See 241 Cal. Rptr. at 544-45.

103 See Frame v. Merrill Lynch, Pierce, Fenner \& Smith, Inc., 97 Cal. Rptr. 811, 814 (Ct. App. 1971) (applying California law to invalidate profit-sharing plan that terminated benefits if former employee competed with employer despite plan's validity under New York law and contractual designation of New York law as controlling); Scott, 732 F. Supp. at $1039-40$ ("[S]ection $16600 \ldots$. . has been held by the California courts to represent a strong public policy which would override the choice of law provision in the contract ....").

104 See supra note 70 and accompanying text. 
employee career pattern, lack of vertical integration, knowledge spillovers, and business culture. Thus, the initial condition supplied by Silicon Valley's legal infrastructure ultimately generated the conditions necessary to support a second-stage agglomeration economy, which allowed it to reset its product cycle and thrive while Route 128 rode its product cycle down the curve.

\section{Solving the Collective Action Problem}

The analysis in the previous section sets out the role played by Business and Professions Code section 16600 as an initial condition of the strategic dynamic set in place by the growth of Silicon Valley. As I argued in Part II, establishing a second-stage agglomeration economy in the absence of a supporting legal infrastructure poses a collective action problem for an industrial district. The collectively rational strategy is to allow high velocity employment, because the per firm benefit of the economy exceeds the per firm cost of the intellectual property dilution that results from the knowledge spillovers necessary to support the economy. However, the individually rational strategy is for a single firm, and therefore every firm, to take advantage of spillovers from the other firms but to restrict the mobility of its own employees. An inability to solve the coordination problem would then lock the district into the suboptimal strategy (and resulting career patterns, industrial organization, and business culture) dictated by the prisoners' dilemma confronting the district.

The existence of Business and Professions Code section 16600 provided the coordination mechanism necessary to overcome this barrier to the development of a second-stage agglomeration economy. By prohibiting covenants not to compete, section 16600 eliminated the only effective strategy for pursuing the individually rational, but collectively suboptimal, strategy. No communication between firms was necessary to this cooperative outcome. Each firm could discover independently (or from observing the experience of their competitors) that trying to restrict employee mobility was ineffective. At that point, the optimal individual strategy and the optimal collective strategy converged: Silicon Valley's legal infrastructure, in the form of Business and Profession Code section 16600's prohibition of covenants not to compete, provided a pole around which Silicon Valley's characteristic business culture and structure precipitated.105

105 Had employers remained persuaded even after a litigation strategy failed that the cost of lost intellectual property exceeded the benefit of the knowledge spillover driven agglomeration economy, they could have contracted around the problem despite Business and Professions Code section 16600 . Since the effect of prohibiting postemployment covenants not to compete is to transfer tacit trade secrets to employees, employers could reduce 


\section{An Alternative Explanation}

Alan Hyde has told a different story about the source of high velocity employment in Silicon Valley. While his account shares my emphasis on the importance of the legal infrastructure, he finds the critical element not the prohibition of covenants not to compete, but California's effective elimination of trade secret protection. ${ }^{106}$ While I agree with much of Professor Hyde's insightful analysis of the phenomenon that has claimed both of our attentions, on the question of identifying the operative element of Silicon Valley's legal infrastructure, I am afraid he has the wrong culprit.

Hyde rejects the influence of covenants not to compete, based largely on dicta in a number of cases that section 16600 does not prohibit covenants not to compete in support of trade secrets. 107 Because misappropriation of trade secrets is independently prohibited, and if covenants not to compete are enforceable if a trade secret is established, then in his analysis covenants not to compete add nothing to

wages to reflect the value of the transferred property right. In effect, the employers' inability to protect proprietary tacit knowledge renders it part of the employees' general human capital - that is, capital that is valuable to employees in alternative employment. Under standard human capital analysis, employees pay for the development of general human capital through lower wages because they retain its continuing benefit. See Gary S. Becker, Human Capital 33-40 (3d ed. 1993).

It is apparent that Silicon Valley employers did not follow this strategy. There is no evidence that Silicon Valley salaries are systematically lower than those in Route 128, where employees can be constrained by postemployment covenants not to compete and, therefore, where proprietary tacit knowledge remains specific human capital paid for by employers because it is of no value to employees in alternative employment. Cf. id. at 40 . 51 (showing that completely specific training should have no effect on wages).

Alternatively, Silicon Valley employers could have protected their investment in proprietary tacit knowledge by arranging production so that employees did not learn enough about the employers' intellectual property for it to become embedded in the employees' human capital. Of course, this strategy would have substantial efficiency costs given the reason that the proprietary knowledge was tacit in the first place. Again, Silicon Valley employers appear not to have followed this strategy either, since Route 128 employers, who are not subject to the inefficiency resulting from this response to California's statutory constraint on intellectual property rights, have not outperformed their Silicon Valley competitors. See supra notes 2, 34-36.

The explanation for the absence of this kind of a Coasian response to section 16600 is likely the employers' experience that the net effect of high velocity employment was posltive, together with the development of supportive labor market institutions. At that point, an individual employer that sought to reduce wages would be penalized by the labor market, and one that sought to structure production inefficiently would be penalized by the product market. Learning through experience the benefit of the agglomeration economy created by high velocity employment made an available Coasian response unappealing to employers. I am grateful to participants at the University of Chicago Law School Law and Economics Workshop for stressing the importance of considering a Coasian response to section 16600.

106 See Hyde, supra note 9, at 25.

107 See id. at 26-28. 
whatever protection is already provided by trade secret law. The operative element therefore must be the extent of trade secret protection. And the difference between Silicon Valley and Route 128's legal infrastructure then must be a difference in the rigor of trade secret law in California and Massachusetts.

My initial problem with the analysis is that Professor Hyde provides neither caselaw nor commentary supporting the proposition that California trade secret law is less favorable to employers than that of Massachusetts. Indeed, the formal evidence cuts the other way. When California adopted the UTA in 1985, it made a significant change in the National Conference of Commissioners on Uniform State Laws's model statute. The model statute defines the confidentiality element of the definition of a trade secret as information that derives value "from not being generally known to, and not being readily ascertainable by . . . other persons." 103 Under this provision, all trade secret protection is lost if a trade secret is available through public sources, regardless of whether a defendant actually obtained the trade secret in so innocent a manner. ${ }^{109}$ The California legislature replaced the italicized phrase, thereby providing broader trade secret protection than the model act.110 So if there were a narrowing of trade secret protection in California, the culprit was not the legislature.

Perhaps the culprit was the courts, although Hyde does not offer case support for the proposition that California judges uniquely weakened trade secret protection. Nor does Hyde offer an explanation of the dynamic by which judicial respect for trade secret protection deteriorated. While courts had to confront section 16600 at the time the conflict over employee mobility began in the early years of Silicon Valley, what moved them to dilute trade secret protection over the vigorous objections of this new business community? And why was the outcome different than in Massachusetts? One might echo Sax-

108 Unif. Trade Secrets Act §1(4) (amended 1985), 14 U.L.A. 438 (1990) (emphasis added).

109 See Merges et al., supra note 94, at 44-45.

110 The legislature rewrote the statute to read that information is not a trade secret if it is "generally known to the public or to other persons," rather than if it is "generally known" or "readily ascertainable." See Cal. Civ. Code \$3426.1(d)(1) (West 1997); Merges et al., supra note 94 , at $44 \&$ n.12 (noting that California modified UTA language by replacing reference to "readily ascertainable"). Although the statutory notes to this section indicate that the change was intended to remove "ambiguity" in the language, the courts have treated the provision as affording broader protection than the UTA. See, e.g., ABBA Rubber Co. v. Seaquist, 286 Cal. Rptr. 518, 528 (Ct. App. 1991) (holding that customer list can be trade secret even if information it contains was available from trade directory). 
enian's proffer of culture, but as we have seen, that still leaves us in search of an explanation for the culture. ${ }^{111}$

Hyde's perfunctory concern with the California courts and legislature is best explained by his interesting identification of a different suspect. $\mathrm{He}$ argues that Silicon Valley lawyers subverted trade secret protection. ${ }^{12}$ Here Hyde draws on literature that assigns these lawyers the special "West Coast" transactional role of facilitator rather than the "East Coast" role of problem raiser. ${ }^{113}$ Hyde reports that Silicon Valley lawyers who, in connection with the closing of venture capital financing, provide investors with the legal opinion that the start-up company has the right to use its technology, employ a narrower definition of trade secret than the courts and the California statute. 114 The explanation for this practice is that the lawyers know that the former employer of the start-up's founders will not sue anyway. In Hyde's view this protection comes not necessarily because trade secret law is unfavorable, but because the reputational consequences

111 See supra text accompanying notes 61-64 (summarizing Saxenian's cultural argument for differences in Silicon Valley and Route 128). There is evidence, of the variety captured by the comment that a lawyer's definition of data is the plural of anecdote, that real actors think the difference between California and Massachusetts law governing covenants not to compete is important. In Ferrofluidics Corp. v. Advanced Vacuum Components, Inc., 968 F.2d 1463 (1st Cir. 1992), Ferrofluidics Corporation, a producer of magnetic fluid rotary seals used in the manufacture of semiconductor chips, hired Sickles as a product manager of its Seals Division in 1985, and thereafter promoted him to general manager of the division. See id. at 1465. In 1990, when "Ferro was suffering, along with much of the New England high-tech industry, from a downturn in the economy," id., Sickles accepted an offer from the Nippon Ferrofluidics Corporation (NFC) (which had been Ferro's Japanese subsidiary) to start a competing magnetic seal rotary fluid business in the United States. See id.

Sickles moved to California to start the new venture, Advanced Vacuum Components, Inc. (AVC), in the hope that he could evade his noncompete covenant by subjecting the new business to California law. See id. at 1466. Sickles had "received advice from lawyers on several occasions, some of which he in turn related to NFC, including the nugget that '[1]egal complications will be greatly reduced by incorporating [the new venture] in California since this state strongly protects the entrepreneur and, in general, does not recognize non-compete agreements.'” Id. (alterations in original) (quotation unattributed). In 1991, AVC and Ferro "raced to the courthouse": AVC requested a judicial declaration invalidating his restrictive covenant under California law; Ferro initiated a lawsuit to enforce the covenant in New Hampshire Federal District Court (which applied New Hampshire law despite the terms of the covenant itself). See id. at 1466-67. Ferro won the race as the district court issued a permanent injunction enforcing the covenant for three years. See id. at 1467. On appeal, the First Circuit upheld the injunction and avoided the choice of law question, but noted that the result would be no different under Massachusetts law. See id. at 1471 .

112 See Hyde, supra note 9, at 33.

113 See Mark C. Suchman \& Mia L. Cahill, The Hired Gun as Facilitator: Lawyers and the Suppression of Business Disputes in Silicon Valley, 21 L. \& Soc. Inquiry 679, 690-91 (1996) (describing Silicon Valley lawyers as facilitators of economic development).

114 See Hyde, supra note 9, at 33. 
to the former employer in the labor market will outweigh the gains from enforcing its intellectual property rights.115 Anticipating this analysis, lawyers are more aggressive in their opinions than the law on the books alone would warrant, because a claim will never be made challenging their opinion.

Reliance on reputational effects is not helpful here, because the reputation argument presumes a business culture that supports highvelocity employment. Yet the very point of establishing the initial conditions that give rise to the second-stage agglomeration economy is to explain the existence of that business culture. Moreover, we still have no explanation for the origins of the differences between the two districts' legal infrastructures. Finally, there is also a more straightforward explanation for the Silicon Valley lawyers' conduct. As I argued in Part III.A, enforcement of trade secret claims in Massachusetts confronts significant procedural and substantive barriers. The closing opinions said to be given by Silicon Valley lawyers are also consistent with what appears to be the "law in action" in Massachusetts. Covenants not to compete are said to provide employers critical additional protection in Massachusetts precisely because trade secret protection of tacit knowledge is ineffective. Thus, the likelihood of a subsequent challenge to an aggressive lawyer's opinion is similarly reduced.

In the end, the different treatment of postemployment covenants not to compete remains the most likely difference in the legal infrastructures of Silicon Valley and Route 128 that led the two districts down their ultimately quite different paths. But although the analysis thus far explains the importance of the legal infrastructure to high technology industrial districts, it still is one step short of explaining the source of the initial conditions in Silicon Valley.

\section{IV \\ SERENDIPITY}

Identifying Business and Professions Code section 16600 as a key factor precipitating Route 128's distinct business culture still leaves one critical question unanswered. We need to know the origins of this unusual statute to identify fully the initial conditions that led to the second-stage agglomeration economy that provided Silicon Valley's salvation. And here the special role of serendipity, of the importance of historical accident stressed by Arthur and Krugman, ${ }^{116}$ takes center stage. Section 16600 was not the result of the prescience of the California legislature. Rather, it grew out of the nineteenth century coin-

115 See id. at 135-38.

116 See supra notes 25-26 and accompanying text. 
cidence of the codification movement in American law, personified by the efforts of David Dudley Field in New York, and the need for a new state to bring some order to the chaotic condition of its laws following its admission to the Union.

The history of California Business and Professions Code section 16600 begins in New York in 1847. In that year, Field was appointed as one of three commissioners charged by the recently adopted New York Constitution "to revise, reform, simplify and abridge the rules and practice, pleadings, forms and proceedings of the courts of record of this State."117 Field dominated the process, which resulted in a revolutionary civil procedure code that the New York legislature promptly enacted. ${ }^{118}$ Field's efforts continued in 1847, when the New York legislature appointed him to the Code Commission charged with codifying substantive law. ${ }^{119}$ Despite the controversy associated with his efforts, ${ }^{120}$ Field produced a Civil Code in 1865,121 but the Code was never enacted in New York. ${ }^{122}$ Instead, it found its only home in the West. The needs of newly admitted states, especially California, to impose some order on jurisdictions with conflicting legal traditions and no single body of law coincided with the peak of Field's codification crusade..$^{123}$ Field found a special ally in California, his brother Stephen J. Field, a member of the California legislature at the time the

117 N.Y. Const. of 1846 , art. VI, $\S 24$.

118 See Lawrence M. Friedman, A History of American Law 391 (2d ed. 1985) (describing history of Field's codification efforts).

119 See id.

120 Friedman notes: "The codification movement is one of the set pieces of American legal history. It has its hero, Field; its villain is James C. Carter of New York, who fought the idea of codification with as much vigor as Field fought for it." Id. at 403 (footnote omitted).

121 See Daun van Ee, David Dudley Field and the Reconstruction of the Law 51 (American Legal and Constitutional History: A Garland Series of Outstanding Dissertations (Harold Hyman \& Stuart Bruchey eds., 1986)).

122 The Civil Code twice was passed by both houses of the New York legislature between 1879 and 1882, but was vetoed by the governor both times. See Mathias Reimann, The Historical School Against Codification: Savigny, Carter, and the Defeat of the New York Civil Code, 37 Am. J. Comp. L. 95, 101 (1989) (documenting codification efforts in New York). Reimann places the Civil Code at the very center of the conflict over codification: "The bone of contention ... was the Civil Code-for Field the centerpiece of his whole agenda, for Carter its truly pernicious part." Id. at 99-100 (footnote omitted). Field's Code Commission also produced a Political Code in 1860, and a Penal Code in 1864. See van Ee, supra note 121, at 50 . The Penal Code was ultimately adopted in 1882. See Reimann, supra, at 99.

${ }^{123}$ See Arvo Van Alstyne, Introduction to West's Annotated California Codes, Civil Code 1 (1954) ("From the raising of the American flag by Commodore Sloat at Monterey on July 7,1846 to the organization of constitutional state government in 1849 , the legal history of California is one of disorder and confusion."); Rosamond Parma, The History of the Adoption of the Codes of California, 22 L. Libr. J. 8, 8-9 (1929) (outlining disarray of California law upon entering Union in 1850). 
state adopted Field's Civil Procedure Code in 1851,124 and later Chief Justice of the California Supreme Court and an Associate Justice of the United States Supreme Court.125

In 1850, the California legislature officially adopted the "common law of England"126 to supplant pre-statehood Spanish and Mexican law. However, the extensive reach of the old Mexican land grant system, together with the overriding federal exceptions carved out by the Treaty of Guadalupe Hidalgo which ended the Mexican-American War in 1848, ${ }^{127}$ diminished the effect of legislation attempting to abolish and repeal all prior law in California. ${ }^{128}$ A contemporaneous account captures the chaotic legal environment:

It is safe to say that, even in the experience of new countries hastily settled by heterogeneous crowds of strangers from all countries, no such example of legal or judicial difficulties was ever before presented as has been illustrated in the history of California. There was no general or common source of jurisprudence. Law was to be administered almost without a standard. There was the civil law, as adulterated or modified by Mexican provincialism, usages, and habitudes, for a great part of the litigation; and there was the common law for another part, but what that was was to be decided from the conflicting decisions of any number of courts in America and England .....129

Consequently, throughout the 1860s, a series of governors, including Leland Stanford, urged a codification of California's laws. ${ }^{130}$ After a

124 Field introduced both the Codes of Civil and Criminal Procedure in the California legislature. See Stephen J. Field, Personal Reminiscences of Early Days in California 72 (Da Capo Press 1968) (1893).

125 See Van Alstyne, supra note 123, at 6.

126 See Act of Apr. 13, 1850, ch. 95, 1849 Cal. Stat. 219 (current version at Cal. Civ. Code $\$ 22.2$ (West 1997)) (stating that common law of England, "so far as it is not repugnant to or inconsistent with the Constitution of the United States, or the laws of the State of California," provides rule of decision in California courts).

127 Treaty of Peace, Friendship, Limits, and Settlement, Feb. 2, 1848, U.S.-Mex., 9 Stat. 922 (1862).

128 That legislation stated:

[A]II laws now in force in this State, except such as have been passed or adopted by the Legislature, are hereby repealed: Provided, however, that no rights acquired, contracts made, or suits pending, shall be affected thereby; and Provided that the laws relating to "Jueces del Campo," or Judges of the Plains, shall be excepted, until provision is made for that office by law; and Provided, also that such repeal shall not affect any Constitutional Laws or Acts of Congress, or any of the stipulations contained in the Treaty of Peace between the United States and Mexico, ratified at Queretaro, the 30th day of May, 1848.

Act of Apr. 22, 1850, ch. 125, 1849 Cal. Stat. 342.

129 Judge Joseph G. Baldwin, The Career of Judge Field on the Supreme Bench of California, Sacramento Union, May 6, 1863, reprinted in Field, supra note 124, at 111, 113.

130 See Parma, supra note 123, at 13 (detailing history of codification effort). 
false start in 1868 , the legislature in 1870 appointed a commission to revise and compile the laws of the State of California. ${ }^{131}$

The commission moved promptly the next year to adopt Field's proposed New York Civil Code in total. ${ }^{132}$ Indeed, the Commission's original version of the California Civil Code contained most of the New York commission's annotations, although as adopted by the legislature in 1872 the Code replaced the direct citations to the New York Civil Code with references to California cases. It was in section 833 of Field's proposed New York Code, adopted verbatim by the California legislature in 1872,133 that we find the precursor of Business and Professions Code section 16600.

Section 833 of the proposed New York Civil Code and the 1872 California Civil Code provided the general rule:

Section 833. Every Contract by which anyone is restrained from exercising a lawful trade or business of any kind, otherwise than as provided by the next two sections, is to that extent void. ${ }^{134}$

The following two sections contained exceptions for covenants not to compete in connection with the sale of a business or the dissolution of a partnership:

131 See id. at 15. A commission was appointed in May 1868, but committed political suicide by announcing its intention to repeal the grand jury system. The legislature disbanded the original commission and empowered its replacement to disregard the work of its predecessors. See id. at 14-15. By this time, Stephen Field was serving as an Associate Justice of the United States Supreme Court.

132 In its preface to the draft of the Civil Code, the Commission stated:

The citizen and the lawyer alike complain over the want of a condensed methodical expression of the law. The Civil Code of New York-a monument of legal wisdom and patient industry-is a collection of Common Law rules and principles, combined with a consolidation of statutes like our own, all concisely stated, logically and harmoniously arranged, in order of subjects corresponding to Blackstone's Commentaries.

Code Commissioners, Preface to Revised Laws of the State of California iv (1871).

133 Following California's lead, the Dakota Territory adopted a similar civil code in 1877, which also acknowledged the influence of the New York Civil Code and the more recent California Civil Code. See George H. Hand, Preface to Revised Codes of the Territory of Dakota iv (1883). When the territory became two separate states, each retained the Code. Montana followed in 1895 with a similar civil code, also acknowledging New York and California. See Mont. Civ. Code $\$ \$ 1-4674$ (1895); see also Andrew P. Morriss, "This State Will Soon Have Plenty of Laws"-Lessons From One Hundred Years of Codification in Montana, 56 Mont. L. Rev. 359 (1995). Lawrence Friedman provides an interesting explanation of the Field Civil Code's success in the West:

The success of the codes in the West was due to reasons that by now are familiar. These were sparsely settled states in a hurry to ingest a legal system. A few had something of a civil-law tradition. In none of the Western states did the bar have a strong vested interest in the continuance of old rules, especially rules of pleading.

Friedman, supra note 118 , at 406 .

134 Compare N.Y. Civ. Code $\S 833$ (1865), with Cal. Civ. Code $\S 1673$ (1872). 
Section 834. One who sells the good will of a business may agree with the buyer to refrain from carrying on a similar business within a specified county, so long as the buyer, or any person deriving title to the good will through him, carries on a like business. ${ }^{135}$

Section 835. Partners may, upon or in anticipation of a dissolution of a partnership, agree that none of them will carry on a similar business within the same city or town where the partnership business has been transacted, or within a specified part thereof. ${ }^{136}$

Parts of Field's formulation reflected the state of the law on restraints at that time in New York and elsewhere. By this point, courts in England applied a rule of reason to evaluate contractual restrictions on the conduct of a trade or business. ${ }^{137}$ From the time of Mitchel $v$. Reynolds ${ }^{138}$ in 1711, English law distinguished between postemployment contractual restraints on employees, and restraints arising out of the sale of a business. ${ }^{139}$ The latter generally were upheld, but the former were held to more rigorous scrutiny and unreasonable restraints-in duration or coverage-were struck down. ${ }^{140}$ This approach ultimately grew into a "rule of reason" that required judicial balancing of interests, including those of the public, in determining a restriction's validity. American law generally followed the English pattern, albeit with special concern for the interests of employees. ${ }^{141}$ But except for a period during which general restrictions-those whose application was not limited geographically-were routinely invalidated, American courts did not apply a per se rule of invalidity with respect to either postemployment restraints or those associated with the sale of a business. ${ }^{142}$

For our purposes, the sequence of sections 833 through 835 differs from the presently existing body of law in one critical respect. While sections 834 and 835 carry forward the existing law's sanction of covenants not to compete associated with the sale of a business, sec-

135. Compare N.Y. Civ. Code $\$ 834$ (1865), with Cal. Civ. Code $\$ 1674$ (1872).

- 136 Compare N.Y. Civ. Code $\$ 835$ (1865), with Cal. Civ. Code $\$ 1675$ (1872).

137 See Blake, supra note 88, at 639-40 (discussing Horner v. Graves, 7 Bing. 735, 131 Eng. Rep. 284 (C.P. 1831), and Hitchcock v. Coker, 113 Eng. Rep. 167 (Ex. 1837)).

13824 Eng. Rep. 347, 348 (K.B. 1711) (holding that contract with lessee of bakehouse not to compete as baker in same parish as lessor "ought to be maintained").

139 Mitchel $v$. Reynolds established the reasonableness standard for restraints attached to the transfer of a business. Id. In the years leading up to Mirchel $v$. Reynolds, "the courts recognized that agreements not to compete given in connection with the sale of a business was [sic] different from normal employee restrictive covenants." Valiulis, supra note 88 , at 159.

140 See Valiulis, supra note 88 , at $162-63$.

141 See Blake, supra note 88, at 643-44 (noting that in United States, "more emphasis was placed on protecting the employee from overly heavy burdens and less on the conclusiveness of contractual terms").

142 Blake, supra note 88 , at $629-44$, develops this history. 
tion 833 voids all other restraints, including especially postemployment covenants not to compete.

It is impossible to know exactly what Field had in mind in this sequence. These sections were added late in the development of the Code, and had not been part of the preliminary draft circulated to judges and lawyers in $1862 .{ }^{143}$ The comment to section 833 expresses a concern that "contracts in restraint of trade have been allowed, by modern decisions, to a very dangerous extent," 144 and refers to two cases: Dunlop v. Gregory ${ }^{145}$ and Whittaker v. Howe. ${ }^{146}$ Both cases involve noncompetition covenants associated with the sale of a business. In Dunlop v. Gregory, the Hudson River Steamboat Association, which operated a passenger service on the Hudson River between New York, Albany, and Troy, owned five boats outright, and two-thirds of a sixth. ${ }^{147}$ A covenant not to operate a passenger boat north of Saugerties on the Hudson was attached to the Association's purchase of the remaining one-third interest in the jointly owned boat. ${ }^{148}$ In Whittaker v. Howe, a covenant not to compete anywhere in Great Britain for twenty years was attached to the sale of a law practice. ${ }^{149}$ The comment to section 833 makes no reference to postemployment covenants not to compete. ${ }^{150}$

The comments to the California Civil Code provide no more guidance. Sections 833 through 835 of the proposed New York Code became sections 1673 through 1675 of the California Civil Code. The California Code Commissioners' 1871 draft contains only a citation to the New York section, and the text of the New York comment. ${ }^{151}$ The 1872 official version expands the original New York comment to include references to California cases. ${ }^{152}$ However, these cases, like

\footnotetext{
143 Compare N.Y. Civ. Code $\S 833$ (1865), with N.Y. Civ. Code (draft 1862).

144 See N.Y. Civ. Code $\$ 833$, cmt. (1865).

14510 N.Y. 241 (1851).

14649 Eng. Rep. 150 (M.R. 1841).

147 See Dunlop, 10 N.Y. at 241.

148 See id. at 242.

149 See Whittaker, 49 Eng. Rep. at 150.

150 The comments to sections 834 and 835 add nothing to the analysis. Both refer only to the need to specify accurately the breadth of an allowable covenant not to compete, and neither contains case citations. See N.Y. Civ. Code $\$ \S 833 \mathrm{cmt}$., $834 \mathrm{cmt}$. (1865).

151 See Cal. Revised Laws $\$ 1673$ (1871).

152 See Cal. Civ. Code $\S \S 1673-1675 \mathrm{cmt}$. (1872) (citing More v. Bonnet, 40 Cal. 251, 254 55 (1870)) (involving contract not to practice asphalt roofing or pavement laying if purchaser of tools for such business became delinquent in payments); Wright v. Ryder, 36 Cal. 342,361 (1868) (involving contract upon sale of boat disallowing boat to run on any rivers, bays, or waters of State of California); California Steamboat Navigation Co. v. Wright, 6 Cal. 258, 262 (1856) (involving contract not to allow boat to navigate certain waters of California for three years where consideration was paid).
} 
those discussed by the New York annotation, do not deal with postemployment covenants not to compete. ${ }^{153}$

Thus, beginning with the enactment of the Civil Code in 1872, California law on postemployment covenants not to compete diverged from that of Massachusetts and the rest of the large industrial states. The rule of reason, clearly in place in Massachusetts by $1869^{154}$ and adopted in New York by 1887,155 came to cover postemployment covenants. Subsequent revision of the California codes made minor changes in the language of sections 1673 through 1675, and moved the sections from the Civil Code to their present place as sections 16600 through 16602 of the Business and Professions Code. However, the substantive peculiarity of California law remained intact until the 1960s. ${ }^{156}$ At that point the development of a high technology industrial district in Silicon Valley brought this serendipitous element of California's legal infrastructure to center stage. Field's accident of history then served as the coordinating mechanism which supported a second-stage agglomeration economy. The rest, as they say, is history.

\section{$\mathrm{V}$ \\ Implications: Three Cautionary Notes}

My account of the role of the legal infrastructure of high technology industrial districts is now complete. The new economic geography stresses the importance of initial conditions in shaping an industrial district's business culture and industrial organization. The presence in Silicon Valley of a second-stage agglomeration economy based on intercompany knowledge spillovers has allowed that district to reset its product cycle repeatedly. The absence of such spillovers in Route 128 has left that district to ride down the product cycle associated with the

153 See supra note 152.

154 See Morse Twist Drill \& Mach. Co. v. Morse, 103 Mass. 73, 77 (1869) (holding that noncompetition clause in employment contract was valid and enforceable, as restriction was not "in any way unreasonable").

155 See Diamond Match Co. v. Roeber, 13 N.E. 419, 423 (N.Y. 1857) (enunciating and adopting reasonableness standard in enforcing former employee's covenant not to compete).

156 The growth in the size of the Civil Code resulted in the biggest change: its dismemberment. The 1930 Code Commission suggested that portions of the Civil Code be broken off into separate codes. See Van Alstyne, supra note 123 , at 24 . The Probate Code was the first spin-off in 1931. See ch. 281, 1931 Cal. Stat. 587, 687 (repealing Civil Code $\$ \$ 236-257$, 1270-1409). The Business and Professions Code was created in 1937. See ch. 399,1937 Cal. Stat. 1229. Sections 16600 through 16602 were added to the Business and Professions Code, and sections 1673 through 1675 were deleted from the Civil Code in 1941. See Act of May 31, 1941, ch. 526, 1941 Cal. Stat. 1834, 1847 (noting derivation from Civil Code sections 1673 to 1675 ). The new section 16601 was expanded to include sales of corporate shares as well as sales of good will, but the broad prohibition of employee postemployment covenants remained undisturbed. See id. 
minicomputer. The difference in initial conditions that helps account for the incidence of this economy and the resulting difference in the two districts' long-term success is found in a critical difference in the two districts' legal infrastructures. The rules governing employer-imposed restraints on employee mobility-the mechanism by which intercompany knowledge spillovers take place-differ sharply in the two districts. California law voids such restraints, thereby encouraging knowledge spillovers; Massachusetts law generally enforces them, thereby blocking the critical knowledge spillovers.

Each legal infrastructure gave rise to a dynamic that helped shape each district's characteristic business culture and industrial organization, one compatible with development of a second-stage agglomeration economy and one not. Consistent with the new economic geography's emphasis on the importance of historical accident, the explanation for the two districts' different legal infrastructure lies in the temporal coincidence of California's need for a coherent body of law following statehood, and David Dudley Field's proposed New York Civil Code. In 1872, California adopted without explanation Field's proposed prohibition of postemployment covenants not to compete; Massachusetts, like most other industrial states, instead followed a rule of reason that sanctioned such covenants subject to judicial review of their duration and coverage.

Like any good story, my chronicle of the importance of the legal infrastructure of high technology industrial districts has a number of possible morals, and potentially instructive implications for related debates. In closing I want to take up briefly three such implications. The first concerns the story's implications for the standard law and economics account of the importance of completely protecting property rights in intellectual property. The second deals with a recent line of cases, involving claims of "inevitable disclosure" by departing employees, that threatens to turn trade secret law into a judicially imposed de facto covenant not to compete. The third considers the story's lesson for regional planners seeking to establish or preserve industrial districts. While each of these implications warrants far more attention than is possible here, I want to add a cautionary note that counsels in favor of a more textured, less categorical analysis in each case.

\section{A. The Conflict Between Protecting Property Rights in Intellectual Capital and Second-Stage Agglomeration Economies}

The standard law and economics prescription stresses the importance of fully protecting the property rights of the producers of intellectual property. In the absence of complete protection, producers 
will not capture all of the gains resulting from their efforts, and too little intellectual property will be produced. ${ }^{157}$ The importance of interemployer knowledge spillovers to the second-stage agglomeration economy that has preserved Silicon Valley sounds a note of caution with respect to an unqualified application of the standard analysis. We may need a more textured approach that takes into account the benefit of an industrial-district-preserving agglomeration economy.158 As I suggested earlier, ${ }^{159}$ the comparison is between the average per firm cost of diluted intellectual property protection and the average per firm benefit associated with the preservation of the high technology industrial district.

Of course, which direction the comparison favors is an empirical question, and one that should not be resolved with, as Professor Trebilcock puts it, "casual empiricism that proves nothing." 160 But the difference in performance of Silicon Valley and Route 128 is a little more than casual and, in any event, the absence of empirical evidence hardly resolves the matter in favor of either side of the argument.

We can perhaps advance the issue by using Silicon Valley to frame a kind of sensitivity analysis. The fact is that firms in Silicon Valley have always been free to opt out of California's legal infrastructure. A firm need only move its intellectual-property-producing activities out of California to avoid the property-rights-diluting effect of Business and Professions Code section 16600.161 If in the calculus of a particular firm the cost of diluted property rights protection outweighs the benefit of the agglomeration economy by more than the firm's and its employees' relocation costs, the firm can simply move to, say, Massachusetts. And if the matter were as simple as an unqualified property rights analysis would have it, one would have expected waves of defections. To be sure, some companies have moved operations out of Silicon Valley. However, the migration appears to be of manufacturing and assembly operations, presumably motivated by the increased factor prices resulting from congestion, rather than of the innovative

157 Michael J. Trebilcock, The Common Law of Restraint of Trade: A Legal and Economic Analysis 152-53 (1986), makes the standard argument with respect to giving California employers more tools to protect their intellectual property against departing employees. Edmund W. Kitch, The Law and Economies of Rights in Valuable Information, 9 J. Legal Stud. 683, 710 (1980), also develops this analysis, although he recognizes the anomaly presented by Silicon Valley.

158 Hyde, supra note 9, at 48-50, also develops this point, although our emphasis differs.

159 See supra text following note 68.

160 Trebilcock, supra note 157 , at 153.

161 Indeed, that strategy would have reduced the role of section 16600 as a coordinating mechanism because an alternative strategy to acceptance of high velocity employment would thereby be available: A firm could exit. 
activities whose location would be influenced by the level of intellectual property protection. ${ }^{162}$ Empirical evidence concerning this sort of balance of trade may be available to help resolve the dispute, or at least move the analysis forward.

One piece of casual empiricism, however, should be noted, if only to highlight the kind of phenomenon an unqualified property rights analysis will have to explain. Recently, the large Swiss pharmaceutical company Novartis AG announced that it would invest $\$ 250$ million in a proprietary research institute in genomics, a form of biotechnology in which the large pharmaceuticals typically have bought expertise, rather than develop it themselves. ${ }^{163}$ This investment has as its sole purpose the creation of intellectual property. Where, then, does Novartis site its new intellectual property factory: where the legal infrastructure fully protects intellectual property rights, or where the company will have the benefit of an industrial district? The new facility will be located in La Jolla, California, a burgeoning biotech industrial district ${ }^{164}$ that is, of course, subject to California Business and Professions Code section 16600.165

\section{B. Resisting Inevitable Disclosure Analysis in California}

The "inevitable disclosure" line of cases in trade secret law represents the doctrinal analogue to the classic law and economics emphasis on fully protecting property rights in intellectual property. Under this doctrine, some courts have constructed a noncontractual covenant not to compete by enjoining a departing employee from beginning a new job with a competitor of the former employer. ${ }^{166}$ The injunction is based on a finding that because of the nature of the trade secrets involved, the employee must inevitably use or disclose them in working for a competitor, regardless of the employee's good faith. California courts have not yet considered the inevitable disclosure doctrine, but California practitioners have begun to raise it as an alternative to

162 See Saxenian, supra note 11 , at 93 (describing semiconductor firms' movement of unskilled assembly and test operations to Asia).

163 See Novartis Plans to Build Genetic-Research Center, Wall St. J., Apr. 9, 1998, at A4.

164 See David B. Audretsch \& Paula E. Stephan, Company-Scientist Locational Links: The Case of Biotechnology, 86 Am. Econ. Rev. 641, 642-49 (1996) (describing concentration of biotech firms in San Diego area).

165 To be sure, Novartis had a more focused reason for locating the facility in La Jolla. It will be built adjacent to the Scripps Research Institute, "with which Novartis already has a 10-year, $\$ 200$ million agreement giving Novartis first rights of refusal to discoveries." Lawrence M. Fisher, Novartis Plans to Research Disease Genes: $\$ 250$ Million Center Set for California, N.Y. Times, Apr. 8, 1998, at D5. But this kind of clustering is precisely what is said to result from agglomeration economies.

166 See Milgrim on Trade Secrets, supra note $74, \S 5.02[3][d]$-[e] (citing cases). 
contractual postemployment restrictions. ${ }^{167}$ The importance of a knowledge spillover-based second-stage agglomeration economy to Silicon Valley's repeated renewal strongly suggests that California courts should be quite cautious in allowing the use of an inevitable disclosure claim to evade Business and Professions Code section 16600. The straightforward application of the doctrine should not seriously test a California court's resolve. A more oblique application of the doctrine, which better fits dicta in existing California caselaw, is a more serious threat. 168

Pepsico, Inc. v. Redmond ${ }^{169}$ illustrates the potential reach of the inevitable disclosure doctrine. The litigation was triggered when Quaker Oats hired Redmond, then Pepsico's manager of California sports drink operations, as Vice President-Field Operations for Quaker Oats's Gatorade brand. ${ }^{170}$ At the time Redmond was hired, Pepsico had begun a new marketing and promotion campaign for its "All Sports" beverage, which directly competed with Gatorade. ${ }^{171}$ Although Redmond had not signed a postemployment covenant not to compete, Pepsico sought an injunction barring Redmond from working for Quaker Oats based on the theory that Redmond would inevitably disclose Pepsico's trade secrets. ${ }^{172}$ Relying on the Illinois version of the UTA, the court concluded that Redmond could not help but use his knowledge of Pepsico's proprietary pricing, marketing, and promotion strategies for its sports drink when undertaking precisely the same responsibilities for Quaker Oats's competing brand. How could Redmond plan a strategy for Quaker Oats without relying on what he knew would be Pepsico's reaction? As the district court concluded, "unless Redmond possessed an uncanny ability to compartmentalize information, he would necessarily be making decisions about Gatorade and Snapple by relying on his knowledge of [Pepsico's] trade secrets." 173 On that basis, the court of appeals affirmed the district court's order prohibiting Redmond from beginning work at Quaker Oats for six months.

Pepsico, Inc. illustrates the problem the inevitable disclosure doctrine presents for California courts. Suppose Redmond's new job,

167 See Weiss et al., supra note 77 , at 7-8.

168 See infra notes $182-85$ and accompanying text.

16954 F.3d 1262 (7th Cir. 1995).

170 See id. at $1264-65$.

171 See id. at 1264 .

172 See id. at 1265-66. Presumably the absence of a contractual covenant not to compete reflected the California situs of Redmond's Pepsico employment and the existence of Business and Professions Code section 16600. The case was decided under Illinois law. See id. at 1267.

173 Id. at 1269. 
rather than his old one, had been in California. California law then would have governed the issue. The statutory conflict for a California court is straightforward. On the one hand, Business and Professions Code section 16600 prohibits postemployment covenants not to compete. On the other hand, California's version of the UTA authorizes injunctive relief against misappropriation of trade secrets. ${ }^{174}$ Preventing misappropriation by enjoining postemployment competition creates the statutory friction.

More specifically, the inevitable disclosure doctrine threatens just the type of knowledge spillover that has been so critical to Silicon Valley. It is because of the very character of tacit knowledge that an employee cannot avoid its use. To take an obvious example, a high technology employee frequently learns not only how to make a product, but how not to make it as well-that is, what manufacturing techniques do not work. Knowledge that particular approaches are ineffective is very valuable in a fast moving high technology industry; the time saved not going down dead ends means getting a product to market sooner. How does an employee not use his former employer's proprietary knowledge that an approach will not work if he is working in the same area for a competitor?

The inevitable disclosure doctrine remains controversial outside of California. Although one court has followed Pepsico in enjoining competing employment in the absence of a postemployment covenant not to compete, ${ }^{175}$ others have rejected requests for injunctive relief in the absence of a covenant, ${ }^{176}$ sometimes stating explicitly that this area is for contract. ${ }^{177}$ Moreover, the cases lend themselves to resolution based on a close parsing of the facts. Consistent with the judicial balancing associated with rule-of-reason review of contractual postemployment restrictions (and the standard balancing of the equities required for injunctive relief), courts relying on the inevitable disclo-

174 See Cal. Civ. Code $\$ 3426.2($ a) (West 1997).

175 See Merck \& Co., Inc. v. Lyon, 941 F. Supp. 1443, 1457-58 (M.D.N.C. 1996) (discussing Pepsico and applying inevitable disclosure doctrine).

176 See, e.g., Campbell Soup Co. v. Giles, 47 F.3d 467, 469 (1st Cir. 1995) (affirming district court's refusal to grant preliminary injunction restraining former employee from working for competitor); Cudahy Co. v. American Labs., Inc., 313 F. Supp. 1339, 1343 (D. Neb. 1970) (noting absence of covenant not to compete in dismissing unfair business practice claim).

177 The district court in Campbell Soup Co. stated that "if Campbell had wanted to protect itself against the competition of former employees, it should have done so by contract. This court will not afford such protection after the fact." Campbell Soup Co. v. Giles, No. 94-40177-NMG (D. Mass. Dec. 12, 1994), quoted in Anthony A. Bongiorno \& James J. Marcellino, Noncompetes: Worth Their Weight on Paper?, Mass. Law. Wkly., Oct. 28, 1996, at 11. 
sure doctrine have stressed employee misbehavior in justifying an injunction. ${ }^{178}$

The inevitable disclosure doctrine can come before California courts in two ways: directly in support of injunctive relief despite the absence of a postemployment covenant not to compete; and indirectly in support of enforcement of an existing contractual restriction. California courts are likely to confront the issue first in its direct form. ${ }^{179}$ Given the state's long history of prohibiting covenants not to compete, few firms will have required their employees to sign contracts widely understood in the legal and business communities to be unenforceable. In this guise, a California court should have little difficulty concluding that Business and Professions Code section 16600 forecloses the use of the inevitable disclosure doctrine to create a de facto covenant not to compete. California courts routinely have seen through other efforts to accomplish indirectly what section 16600 prohibits directly. 180 The UTA's general authorization of injunctive relief hardly trumps such a long-standing and specific statutory prohibition. ${ }^{181}$

When presented in its indirect form, the inevitable disclosure doctrine is more troublesome. While section 16600 and the UTA plainly

178 See, e.g., APAC Teleservices Inc. v. McCrae, 985 F. Supp. 852 (N.D. Iowa 1997) (granting temporary injunction preventing former employee from revealing trade secrets after finding defendant deceitful in his representations about new employment); Merck \& Co., $941 \mathrm{~F}$. Supp. 1443 (granting preliminary injunction to former employer where employee lied about new employer); Surgived Corp. v. Eye Technology, 648 F. Supp. 661 (D. Minn. 1986) (providing lengthy analysis of former employees' misdeeds before granting permanent injunction against disclosure of trade secrets); cf. Fowler v. Varian Assoes., Inc., 241 Cal. Rptr. 539, 545 (Ct. App. 1987) (discussing former employee's failure to disclose disloyalty to employer and rejecting his claim that discharge violated free-competition public policy evidenced by $\S 16600$ ).

179 The inevitable disclosure doctrine is said to have been before the Califormia Superior Court for Santa Clara County in Advanced Micro Devices, Inc. v. Hyundai Electronies America, No. CV752679 (Super. Ct. 1996). See Weiss et al., supra note 77 (describing unpublished order in that case granting preliminary injunction enjoining five former Advanced Micro Devices employees from working on specific technology at new employer); see also Hanna Bui-Eve, To Hire or Not to Hire: What Silicon Valley Companies Should Know About Hiring Competitors' Employees, 48 Hastings LJ. 981, 998 (1997) (discussing use of inevitable disclosure doctrine in California courts).

180 See supra note 100.

181 Post-Pepsico caselaw is consistent with this distinction. In most cases, inevitable disclosure analysis is invoked by litigants to justify enforcing a contractual postemployment covenant not to compete under the rule of reason. See La Calhène, Inc. v. Spolyar, 938 F. Supp. 523, 530-31 (W.D. Wis. 1996) (noting inevitability of disclosure and granting preliminary injunction enforcing covenant not to compete); Uncle B's Bakery, Inc. v. O'Rourke, 920 F. Supp. 1405, 1432-33 (N.D. Iowa 1996) (finding non-competition clause reasonable due to fact that former employee, in new job, had opportunity to exploit special knowledge gained from former employer); Lumex, Inc. v. Highsmith, 919 F. Supp. 624, 632 (E.D.N.Y. 1996) (finding covenant not to compete reasonable where disclosure of trade secrets by former employee was inevitable). 
face different directions, California caselaw does suggest an accommodation of the two statutes that would leave room at least doctrinally for enforcing trade secret-based postemployment restrictions. Although in dicta, the California Supreme Court has stated that covenants not to compete are unenforceable "unless necessary to protect the employer's trade secrets," 182 a phrase that has been repeated, equally hypothetically, by other courts. ${ }^{183}$ Now suppose that a wellcounseled employer requires a recent employee to sign a postemployment covenant not to compete whose recitals explicitly invoke the involuntary disclosure doctrine as a justification: that the employee must receive the employer's trade secrets in order to do her work, that the trade secrets are of a character that inevitably would be disclosed if the employer worked for a competitor, and that the covenant not to compete is necessary to protect them. Later, when the employer seeks to enforce the covenant not to compete against the departing employee, the inevitable disclosure doctrine can be rationalized as simply giving substance to an exception to Business and Professions Code section 16600, the potential for which has long been recognized in California law. Of course, such a rationalization would find theoretical support in the law and economics emphasis on protecting property rights to assure the proper incentives to produce intellectual property. ${ }^{184}$

The doctrinal sleight of hand necessary for the inevitable disclosure doctrine's indirect application in California thus does not require a significant judicial stretch. But the analysis of the initial conditions giving rise to Silicon Valley's second-stage agglomeration economy admonishes California courts to exercise great caution before pursuing such an accommodation. Inevitable disclosure doctrine poses a serious threat to the interemployer spillover of proprietary tacit knowledge that allows Silicon Valley to reset its product cycle repeatedly. Given the uncertainty of the theoretical tradeoff between fully protecting property rights and protecting the agglomeration economy that supports the industrial district, courts should be reluctant to alter the legal infrastructure that preserves the existing, and successful, balance. ${ }^{185}$

182 Muggill v. Reuben H. Donnelly Corp., 398 P.2d 147, 149 (Cal. 1965) (quoting Gordon v. Landau, 321 P.2d 456 (Cal. 1958) (in bank)) (noting trade secret exception to section 16600); see also supra text accompanying notes 99-100.

183 See supra note 101 and cases cited therein.

184 See supra note 157.

185 The doctrinal response to the indirect invocation of the inevitable disclosure doctrine is also not difficult to construct. The cases in which courts have floated the possibility that a covenant not to compete could be used to protect a trade secret have involved a tangible trade secret, like customer lists. See, e.g., Milgrim on Trade Secrets, supra note 74, 


\section{Emulating Silicon Valley's Success by Prohibiting Covenants Not to Compete}

My account of the legal infrastructure's role in Silicon Valley's continued success has an obvious implication for regional planners seeking to create or preserve local industrial districts: Simply replicate that aspect of the legal infrastructure that provided the critical initial condition. On this analysis, state legislatures should emulate California by enacting the equivalent of Business and Professions Code section 16600's prohibition of postemployment covenants not to compete. ${ }^{186}$ Again, however, I think caution is in order in assessing the policy implications of Silicon Valley's history.

Evaluating the prohibition of covenants not to compete requires a trade-off between the districtwide benefits of knowledge spillovers through employee mobility, and the costs of the reciprocal reduction in the incentive for intellectual property investment that results from the dilution of employers' property rights. With respect to Silicon Valley and Route 128, the balance seems to have favored agglomeration economies over property rights protection. However, this balance may well be quite local, depending on the characteristics of particular industries. And because industries are not randomly distributed

$\$ 1.09[7]$ (citing cases). As a result, a court is in a position to enforce a narrow definition of competition - one limited to the trade secret's particular tangible manifestation. In effect, the covenant would provide somewhat broader protection than a no solicitation agreement, which the California courts have interpreted as barring direct solicitation of business, but not indirect solicitation by means of the announcement of the employee's new position. It would also parallel the distinction drawn by invention law based on whether written corroboration has triggered conception. See supra text accompanying notes 84-87. Most important, such a narrow scope for the trade secret exception would exclude from the doctrinal accommodation trade secrets involving tacit knowledge and the like which are at the heart of Silicon Valley's knowledge spillover-based agglomeration economy.

186 While I am not aware of any legislature seeking to emulate the California Business and Professions Code section 16600, in recent years the Texas Supreme Court appears to have concluded that enforcing postemployment covenants not to compete is poor policy. See Hill v. Mobile Auto Trim, Inc., 725 S.W.2d 168, 172 (Tex. 1987) (rejecting traditional rule of reason analysis in favor of prohibiting any covenant that restrains employee's right to engage in "common calling"). The Texas legislature responded in 1989 with the adoption of the Covenants Not to Compete Act, which resurrected traditional standards of enforceability. See ch. 1193, \$ 1, 1989 Tex. Gen. Laws 4852-53, as amended by Act of June 19, 1993, ch. 965, § 1, 1993 Tex. Gen. Laws 4201-02 (codified as amended at Tex. Bus. \& Com. Code Ann. $\$ 15.50$ (West 1987 \& Supp. 1999)). The dialogue between the Texas Supreme Court and legislature continued for another round, this time concerning whether at-will employment was sufficient consideration to support a postemployment covenant. Jeffrey W. Tayon, Covenants Not to Compete in Texas: Shifting Sands From Hill to Light, 3 Tex. Intell. Prop. L.J. 143 (1995), and Crystal L. Landes, Comment, The Story of Covenants Not to Compete in Texas Continues, 33 Hous. L. Rev. 913 (1996), provide accounts of this institutional debate. Given the growth of high technology industry centered in Austin, Texas, this series of events certainly warrants greater attention. I am grateful to Sam Issacharoff for calling the Texas experience to my attention. 
across jurisdictions, each state's particular industrial population may dictate a different balance. Rather than emulating California's blanket prohibition (which, after all, exists by historical accident not design), it may be that the rule of reason currently applied to postemployment covenants not to compete by other industrial states is flexible enough to allow for this kind of industry-by-industry approach. In assessing the validity of a particular covenant under this legal regime, a court balances against the employer's interest in enforcing the covenant not only the employee's interest in mobility, but also the public interest. ${ }^{187}$ At least at the doctrinal level, this formulation invites courts to consider the public interest in a particular potential agglomeration economy, and invites the parties to present expert testimony concerning the knowledge structure of the industry involved.

Robert Merges and Richard Nelson provide some guidance about how such an inquiry might proceed.188 Patent law in general, and the appropriate scope of a patent in particular, present a balancing issue roughly analogous to that presented by the scope of protection provided by the law governing trade secrets and covenants not to compete. Patent law may encourage innovation through either of conflicting means-a broad patent scope rewards innovators with the full economic value of an invention, while a narrow patent scope encourages innovation by making it easier for subsequent investors to improve on existing patented technology. In trade secret law, encouraging innovation through a broad scope for trade secret protectionthat is, by augmenting trade secret law through enforcing covenants not to compete and thereby protecting tacit knowledge and preconception inventions-also conflicts with an alternative means to encourage innovation. A narrow scope for trade secret protection, as with California's prohibition of postemployment covenants not to compete, facilitates second-stage agglomeration economies by leaving tacit knowledge and preconception inventions unprotected.

Merges and Nelson argue that the proper patent scope depends on the nature of innovation in particular industries. ${ }^{189}$ Two of their categories of innovation are instructive for our purpose. The first is "discrete innovation," in which the invention's boundaries are clear and, although subject to improvement, the invention is clearly not the first step in a series of important technical advances. ${ }^{190}$ They offer the

187 See supra text accompanying notes 88-93.

188 See Robert P. Merges \& Richard R. Nelson, On the Complex Economics of Patent Scope, 90 Colum. L. Rev. 839 (1990).

189 See id. at 843 .

190 See id. at 880 . 
ballpoint pen as an example of this type of invention. ${ }^{191}$ The second is "cumulative technologies," in which innovation is additive in the sense that it can be anticipated that fundamental technological advances are both possible and will build on existing technology.192 "Over time dramatic advance occurs in these technologies from improvements to one aspect or another, adding this new feature or that." 193 Computers are an example of this type of technology.

Building on this typology, Merges and Nelson argue that a broad patent scope is appropriate in industries characterized by discrete innovation; encouraging initial discovery by expansive property rights incurs little offsetting cost by discouraging follow-on innovation. ${ }^{194}$ In contrast, a narrow patent scope is appropriate in industries characterized by cumulative technologies; the gains from encouraging follow-on innovation exceed the costs of reduced incentives for initial invention. ${ }^{195}$ The same analysis may be appropriate with respect to trade secret protection. Because Silicon Valley appears to be characterized by cumulative technologies, California's narrow scope of trade secret protection, effected by prohibiting covenants not to compete, would be just about right.

Thus, it may well be that a state concerned with regional development today should not blindly seek to replicate the historical source of Silicon Valley's success. Given the opportunity to act by design rather than by historical accident, the better approach may be to craft a legal infrastructure that has the flexibility to accommodate the different balance between external economies and intellectual property rights protection that may be optimal in different industries. In contrast, for California, where the industrial distribution already reflects the longterm presence of Business and Professions Code section 16600, the best course may simply be staying the course.

191 See id.

192 See id. at 884-97.

193 Id. at 881.

194 See id. at $880-81$.

195 See id. at 908-09. 